\title{
Large-scale use of mosquito larval source management for malaria control in Africa: a cost analysis
}

Eve Worrall ${ }^{1}$ and Ulrike Fillinger $2,3^{*}$

\begin{abstract}
Background: At present, large-scale use of two malaria vector control methods, long-lasting insecticidal nets (LLINS) and indoor residual spraying (IRS) is being scaled up in Africa with substantial funding from donors. A third vector control method, larval source management (LSM), has been historically very successful and is today widely used for mosquito control globally, except in Africa. With increasing risk of insecticide resistance and a shift to more exophilic vectors, LSM is now under re-evaluation for use against afro-tropical vector species. Here the costs of this intervention were evaluated.
\end{abstract}

Methods: The 'ingredients approach' was used to estimate the economic and financial costs per person protected per year (pppy) for large-scale LSM using microbial larvicides in three ecologically diverse settings: (1) the coastal metropolitan area of Dar es Salaam in Tanzania, (2) a highly populated Kenyan highland area (Vihiga District), and (3) a lakeside setting in rural western Kenya (Mbita Division). Two scenarios were examined to investigate the cost implications of using alternative product formulations. Sensitivity analyses on product prices were carried out.

Results: The results show that for programmes using the same granular formulation larviciding costs the least pppy in Dar es Salaam (US\$0.94), approximately 60\% more in Vihiga District (US\$1.50) and the most in Mbita Division (US\$2.50). However, these costs are reduced substantially if an alternative water-dispensable formulation is used; in Vihiga, this would reduce costs to US\$0.79 and, in Mbita Division, to US\$1.94. Larvicide and staff salary costs each accounted for approximately a third of the total economic costs per year. The cost pppy depends mainly on: (1) the type of formulation required for treating different aquatic habitats, (2) the human population density relative to the density of aquatic habitats and (3) the potential to target the intervention in space and/or time.

Conclusion: Costs for LSM compare favourably with costs for IRS and LLINs, especially in areas with moderate and focal malaria transmission where mosquito larval habitats are accessible and well defined. LSM presents an attractive tool to be integrated in ongoing malaria control effort in such settings. Further data on the epidemiological health impact of larviciding is required to establish cost effectiveness.

Keywords: Malaria, cost analyses, vector control, larval control, source management, Bacillus thuringiensis israelensis, Anopheles gambiae

\section{Background}

Malaria research and control in Africa is seeing unprecedented funding support to scale up much needed interventions. The level of funding has increased six-fold from 2003 to 2009 [1]. Key donor sources are the

\footnotetext{
* Correspondence: ulrike.fillinger@lshtm.ac.uk

${ }^{2}$ Department of Disease Control, London School of Hygiene and Tropical Medicine, Keppel Street, London WC1E 7HT, UK

Full list of author information is available at the end of the article
}

President's Malaria Initiative (PMI), Global Fund to Fight AIDS, Tuberculosis and Malaria (GFATM) and the Department for International Development (DfID) [2]. Funds are used to support diagnoses and treatment through artemisinin combination therapy (ACT), rapid diagnostic tests (RDT) and intermitted preventive treatment in pregnant women and infants (IPTp/i). Support for vector control is mostly spent on long-lasting

\section{Biomed Central}


insecticidal nets (LLINs) and, more recently, through PMI on indoor residual spaying (IRS) [3].

Vector control programmes are being encouraged to develop Integrated Vector Management (IVM) strategies for the control of malaria and other vector borne diseases [4]. In IVM, multiple tools are recommended to increase effectiveness and reduce our dependency on insecticides. Larval source management (LSM) might have the capacity to supplement the prioritized vector control measures since it will attack not only the indoor mosquito populations but also those vectors that remain less affected by LLINs and IRS like the outdoor biting and/or resting Anopheles arabiensis or secondary malaria vectors, which are less anthopophilic and sustain low malaria transmission after high LLIN/IRS coverage. Moreover, the wide diversity in the mode of actions of larvicides in combination with environmental modifications and manipulations could be an opportunity to maintain the longevity of widely used active ingredients and offers a means to reduce the overall dependence on insecticides.

Despite its enormous historical successes mosquito larval source management (LSM) remains a largely forgotten and often dismissed intervention for malaria control in Africa [5-15]. One of the reasons LSM is not considered for malaria control is that it is perceived as 'beyond the reach of most resource-deprived communities in sub-Saharan Africa' creating the impression that LSM is far more expensive than other malaria control interventions [16]. However, with increasing risk of insecticide resistance and a shift to more exophilic vectors in response to insecticides indoors LSM is now under re-evaluation for use in Africa[14,17-27].

Recent studies in rural areas of western Kenya have demonstrated that larval control can reduce the abundance of malaria mosquito larvae and adult females by > $90 \%[27,28]$. Furthermore, vector control with microbial larvicides and LLINs combined, resulted in a two-fold reduction in new malaria infections compared with LLINs alone indicating that the addition of anti-larval measures to LLIN programmes provides substantial additional protection against malaria parasites [28]. Similar results have been shown in the city of Dar es Salaam, Tanzania, where LSM is implemented operationally through the Urban Malaria Control Programme [29]. Successes have also been achieved in Eritrea where LSM is included in an integrated vector management programme that has lead to a decrease in malaria of > $50 \%$ [30]. These successes have paved the way for LSM to be included in the Global Malaria Action Plan of the Roll Back Malaria Partnership [31].

This paper aims to complement these efforts by costing the implementation of large-scale LSM using microbial larvicides in three different settings in East Africa.
These analyses aim to quantify the resource implications of delivering large-scale LSM in terms of economic costs per person protected per year (pppy) and total economic programme costs. Estimates can be considered alongside similar analyses that have been prepared for large-scale use of LLINs and IRS [32]. This paper also presents programme designs for different eco-epidemiological settings, including staff requirements, management system and responsibilities to provide assistance for planning similar programmes.

\section{Methods}

Eco-epidemiological settings and LSM programme design

The cost analysis presented here was carried out in 2007. Three settings were included representing different ecologies where LSM programmes had been implemented previously and shown to reduce malaria transmission by 70-90\% [26-29]. Specifically, costs were estimated for: (1) a LSM programme in 15 city wards of urban Dar es Salaam, Tanzania, (2) a district wide LSM programme in Vihiga District (in 2009 divided in Vihiga, Emuhaya, Hamisi and Sabatia District), a highly populated area in the western Kenyan highlands, and (3) a LSM programme along the shores of Lake Victoria covering Mbita Division in Suba District (in 2009 divided in Suba and Mbita District, Mbita Division is since located in Mbita District), western Kenya (Table 1).

All settings experience two rainy seasons each year: the longer season with peak rainfall from approximately March to June, and the shorter season between October and December. For costing, a LSM programme was designed, but not actually implemented, for the three defined intervention areas. Programme design decisions and estimates of the quantity of key resources required were informed by the existing operational programme in Dar es Salaam, Tanzania and small-scale research projects which have been implemented in these sites previously [26-28].

\section{Urban Dar es Salaam}

Dar es Salaam is the largest city in Tanzania; with approximately 2.9 million inhabitants. It has distinctive characteristics of urban malaria ecology and epidemiology. Malaria transmission is seasonal and focal with a moderate average parasite prevalence rate in all-age groups $<10 \%$ [29]. Interestingly, malaria vectors in the city appear to have adapted to high coverage with bed nets and improved housing by predominantly feeding outdoors [33]. Thus, insecticide-treated nets confer slightly less protection than in rural areas so additional measures directed at aquatic stages of vector mosquitoes may have a useful role in this and similar urban settings [33]

At the time of this analysis, the Urban Malaria Control Programme (UMCP) was operating at different stages of implementation in 15 city wards of Dar es 
Table 1 Target location summary

\begin{tabular}{|c|c|c|c|c|c|c|c|}
\hline \multicolumn{3}{|c|}{ Study location } & \multicolumn{4}{|c|}{ Defined Target Areas for Costing LSM programs } & \multirow[t]{2}{*}{ Targeting Strategy } \\
\hline Country & $\begin{array}{l}\text { City/ } \\
\text { District }\end{array}$ & Description & Administrative area covered ${ }^{1}$ & Total Population ${ }^{2}$ & Area in $\mathrm{km}^{2}$ & $\begin{array}{l}\text { Population } \\
\text { density } / \mathrm{km}^{2}\end{array}$ & \\
\hline Tanzania & Dar es Salaam & Urban & 15 city wards & 592,338 & 58 & 10,289 & None \\
\hline Kenya & Vihiga District & Rural highlands & Vihiga District (total 6 divisions) & 609,324 & 563 & 1,082 & Spatial and Tempora \\
\hline Kenya & Suba District & Rural lakeside & Mbita Division & 55,558 & 211 & 263 & Spatial \\
\hline
\end{tabular}

1 Costing in Dar es Salaam is based on ongoing operational program, others are fictive programs based on previous research projects.

2 Vihiga and Mbita population projection based on 1999 census. Kenya 1999 population and housing census. Published 2002 by Central Bureau of Statistics, Ministry of Finance and Planning in Nairobi, Kenya. Dar es Salaam population based on sum of population data for selected wards 2002 Population and Housing Census, National Bureau of Statistics, Tanzania

Salaam (five wards per municipality), an area inhabited by more than 592, 000 people and covering $58 \mathrm{~km}^{2}$ (Table 1). LSM was operational in three of the 15 wards, in the remaining nine wards mapping and mosquito surveillance had been carried out in preparation for the intervention $[26,29,34,35]$. Programme costs (excluding academic research costs) from operational wards were used to estimate the costs for operational LSM in all 15 wards.

\section{Western Kenyan Highlands (rural, high population density site)}

Recently there has been a marked increase in malaria in the African highlands, largely due to the rise of drugresistant strains of Plasmodium falciparum parasites [36-38]. The ecology of the western highlands of Kenya supports stable transmission and increasing population pressure has led to agricultural changes creating ideal conditions for vector proliferation $[19,39]$.

Here costs were estimated for a LSM programme for the entire Vihiga District, one of the most densely populated districts in Kenya. This District was divided into six divisions, 26 locations, and 110 sub-locations. The district had an area of $563 \mathrm{~km}^{2}$ and an estimated population of 609, 324 (Table 1, [40]) and its elevation is 1450-1580 $\mathrm{m}$ altitude. The cost estimations are based on a programme targeted in time with four months larvicide application during the main transmission season $[16,28]$.

Malaria transmission in the district is seasonal and prone to climate related epidemics. A parasite prevalence survey along a transect found that the proportion of children infected with malaria parasites was $68 \%$ in the valley bottom $(1450 \mathrm{~m}), 40 \%$ percent at mid-elevations $(1500 \mathrm{~m})$ and $27 \%$ at the hilltops/summit $(1580 \mathrm{~m})$ [41]. Crucially however, $98 \%$ of Anopheles gambiae s.s. and Anopheles funestus were collected in the valley bottoms [41]. This raises the probability that a larval control intervention targeted spatially at the valley bottoms will also prevent the vast majority, if not all, transmission in populations residing further up the valley sides.

\section{Rural lakeside area (low population density site)}

Mbita Division is situated along the shores of Lake Victoria in western Kenya. It is largely rural and sparsely populated, except for Mbita town. Mbita is one of five administrative divisions of Suba District. It covers approximately $20 \%\left(211 \mathrm{~km}^{2}\right)$ of the surface area of the District and is home to around 55, 558 people (Table 1). Malaria transmission is moderate but perennial with malaria parasite rates ranging between $20-50 \%$ (N. Minakawa, pers. communication). Primary malaria vectors are An. gambiae s.s., An. arabiensis and An. funestus. Their larval habitats are well-defined and are primarily found in close vicinity to the lake shore and close to human habitations $[14,42]$. A longitudinal study over five years in Mbita showed that weekly LSM throughout this period reduced malaria transmission by $>90 \%$ and gave the first indication that such impact might be achieved with moderate costs [27]. Due to the heterogeneous ecology of the different divisions within Suba District and the lack of sufficient baseline knowledge of these, the costing was not extrapolated to the entire district but restricted to Mbita Division. To protect its population, analysis of the topography of the Division revealed that approximately two-thirds of the surface area $\left(140 \mathrm{~km}^{2}\right)$ would need to be included for LSM. Population density in the remaining one third is extremely low and at higher altitude, where aquatic habitats are rare and malaria transmission intensity very low. Hence spatial targeting was also assumed to be a viable strategy in this area.

\section{Costing methodology}

The ingredients approach was utilized by first identifying the activities to be costed, and then quantifying the financial and economic cost of carrying out these activities [43]. The economic cost analysis captured all resources used, including donations and volunteers, as well as the opportunity cost of existing inputs (e.g. staff time, equipment, and buildings which are already employed/in existence) and excluded taxes and other transfer payments where no resources are used. The cost of capital items was spread over their useful life at a discounted rate. Economists use discounting to make 'fair' comparisons of programmes whose costs and outcomes occur at different times. For example it allows 
considering the opportunity cost of tying up resources in capital items and the preference for receiving goods or services sooner rather than later. The economic cost analysis is presented from the provider (or supply) perspective so that the Dar es Salaam financial costing takes perspective of the Government of Tanzania and Vihiga and Mbita financial costing takes perspective of the Government of Kenya. Opportunity costs incurred by the community are not captured; however, these costs would be minimal in a LSM programme operating as described in this paper since all community staff involved in the programme are paid a wage for their time, other involvement would only be allowing access to their property.

\section{Resource requirements}

Resource requirements were estimated by experts from industry, academia and malaria control programmes in Kenya, and Tanzania working together to describe a larval control programme that would be appropriate for the three settings. The experts involved had significant experience designing and managing larval control programmes. The resource requirements were captured and quantified in a spreadsheet model. The LSM programmes designed (see Table 1, Figures 1, 2 and 3) included a preparatory phase (six months) and an intervention phase (one year). Estimates of the quantity of key resources (e.g. larval control persons (LCPs), supervisors, equipment and larvicide) required were informed by small-scale research projects in the planned intervention areas and the UMCP in Dar es Salaam [26-28]. It is assumed that larvicide manufacturer inputs (technical advice) are provided as part of their user service and, therefore, are implicitly captured in the larvicide product price rather than in staffing. Academic technical expertise was included in the costing for all three programme settings but costs of academic research were excluded.

\section{Cost estimation}

Cost estimates for each LSM component (the ingredients') were obtained from a variety of sources, including quotes and invoices for recently purchased equipment. Staff time was valued at full salary costs (mid-range), including allowances according to government pay scales for suitably qualified staff. The opportunity costs of existing Ministry of Health $(\mathrm{MoH})$ employee involvement was estimated based on existing salaries, including allowances. The cost of office and storage space was proxied, based on local rents. The cost of larvicide was based on the midpoint of published ex works 2005 U.S. dollar prices for the formulations (Additional File 1, Table S1: Larvicide Product Prices) [27]. Prices were adjusted to 2006 prices using the U.S. Government estimate of producer price inflation (Additional File 1,
Table S2 US Producer price index industry data "all other basic organic manufacturing" sector: price inflator and deflators). Costs were measured in the currency in which they would be paid (specifically, United Kingdom pound $[€]$, United States dollar [US\$], Kenya shilling [KES], Tanzania shilling [TZS]), and converted into 2006 U.S. dollars using average exchange rates for 2006 (Additional File 1, Table S3: Exchange Rates). Capital costs were annualized using a discount rate of $3 \%$ (Additional File 1, Table S4: Annualization Factors and Discount Rates) and the estimated useful life for specific items (summarized in capital-good unit cost tables in relevant appendices) [44]. Costs incurred during the preparatory phase of each programme were calculated and annualized over their useful life which was assumed to be eight years in line with other studies using a 3\% discount rate $[44,45]$. These were added to the cost of the intervention phase to calculate a typical year's costs.

All costing methodologies were consistently applied across each of the three programme settings. Care was taken to ensure that other assumptions made in the costings were consistent except where programme specific conditions (e.g. vector ecology) necessitated different assumptions.

\section{Larval control product and formulations}

The programmes were costed assuming the use of microbial larvicides for vector control. Commercially available products from Valent BioSciences Corp., Illinois, USA, were used as the basis for costs in this report: VectoBac ${ }^{\mathbb{B}}$ (active ingredient: Bacillus thuringiensis israelensis (Bti)) [46]. The product is available as a water dispersible granule (WG) formulation for liquid application with knapsack sprayers and custom granule (CG) formulations for hand application. These two alternate formulations are designed for different habitats. The WG formulation is stored as a dry product and mixed into water for spraying as a liquid onto open, non-vegetated waters. The CG formulation is a dry granule and is applied to habitats with emergent vegetation, such as rice or wetlands. The granule is sprayed or thrown into the air, falls through the vegetation, and delivers the active ingredient directly to the water's surface. Both WG and CG formulations can be applied using a number of application methods and devices [47]. The volume of product required to treat a similar area is higher for CG than for WG due to differences in the international toxic units (ITU) per mg [13]. This has implications for shipping, transportation, and storage costs, which were all considered in this analysis. All application rates and product use costed here are based on published data [27].

\section{Mapping}

Maps of the intervention areas are essential for programme planning and implementation. In Dar es Salaam 


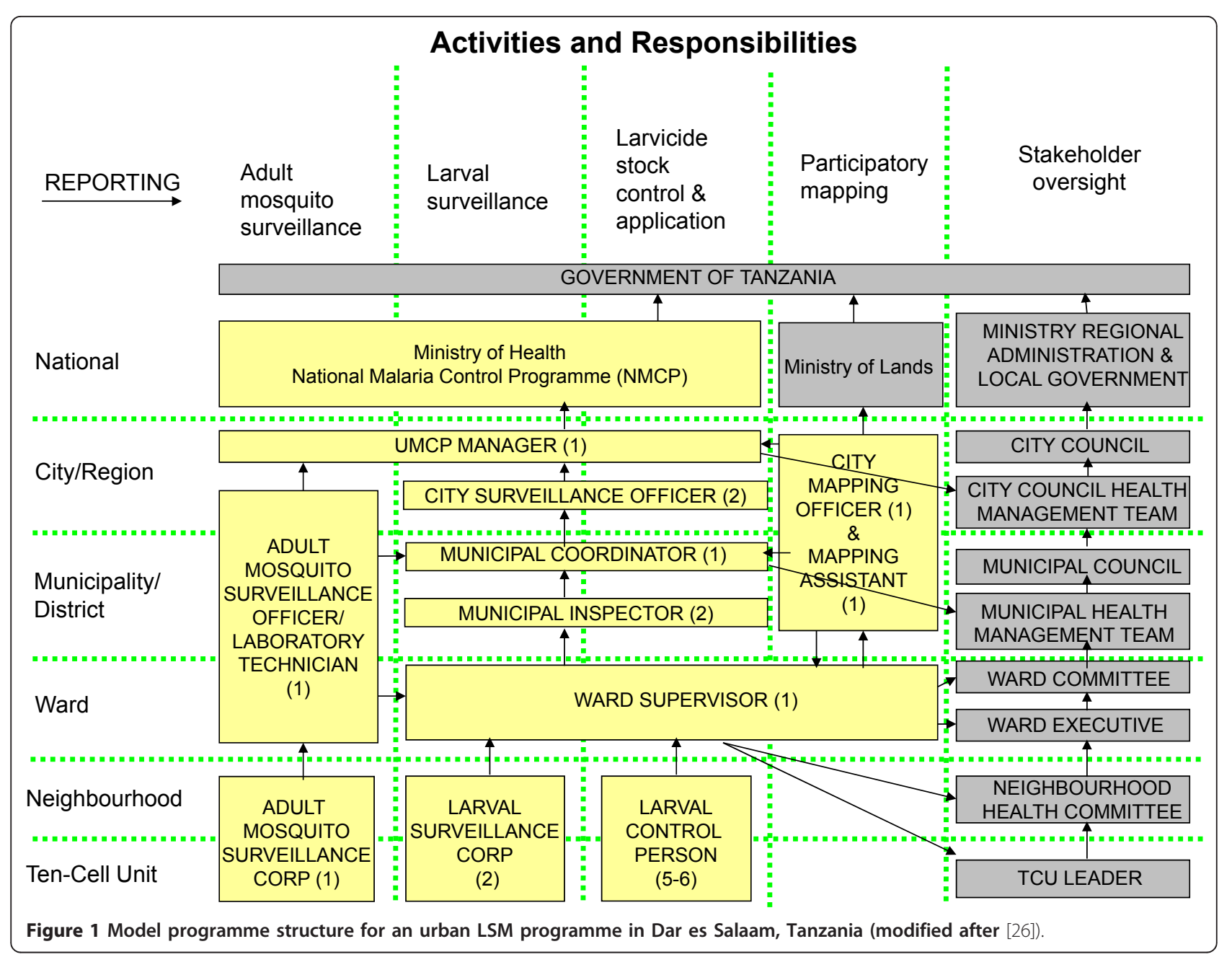

we used the actual costs of purchasing aerial photographs and developing the maps from the UMCP [34]. In Vihiga District we included the cost of purchasing detailed maps of the area and staff time and equipment (GPS units) used to develop maps to guide larvicide application. In Mbita it was not necessary to include the cost of purchasing maps as satellite images of sufficient resolution can be downloaded free of charge from the internet (e.g. Google Earth). GPS units and staff time was included for the development of maps to guide applications.

\section{Monitoring and evaluation}

A monitoring and evaluation (M\&E) component must be an integral part in an operational vector control programme to document progress towards achievement of goals and for data-driven decision making on all levels of the programme [26,48]. LSM programmes need to monitor that: (1) the larvicide works (i.e. larvae dead after 24 hours), (2) LCPs are in the field applying larvicide according to their schedule, and (3) adult vector densities are significantly reduced compared to baseline and are kept at a low level throughout the year. Consequently, spot check larval habitat surveillance for monitoring product efficiency and staff performance and adult mosquito collections were included in the costing of the programmes. M\&E strategies differed in the settings due to the differences in vector ecology, scale of the programmes and programme design. The impact of the intervention on the disease can be assessed through government health records in conjunction with the monitoring of other disease control efforts and was not costed as part of the LSM programme.

\section{Scenario analysis}

Following development of the spreadsheet model for each intervention setting, cost implications of two scenarios using the alternative formulations of VectoBac ${ }^{\circledR}$ were evaluated for Vihiga District (weekly application for four months) and Mbita Division (weekly application all year round). 


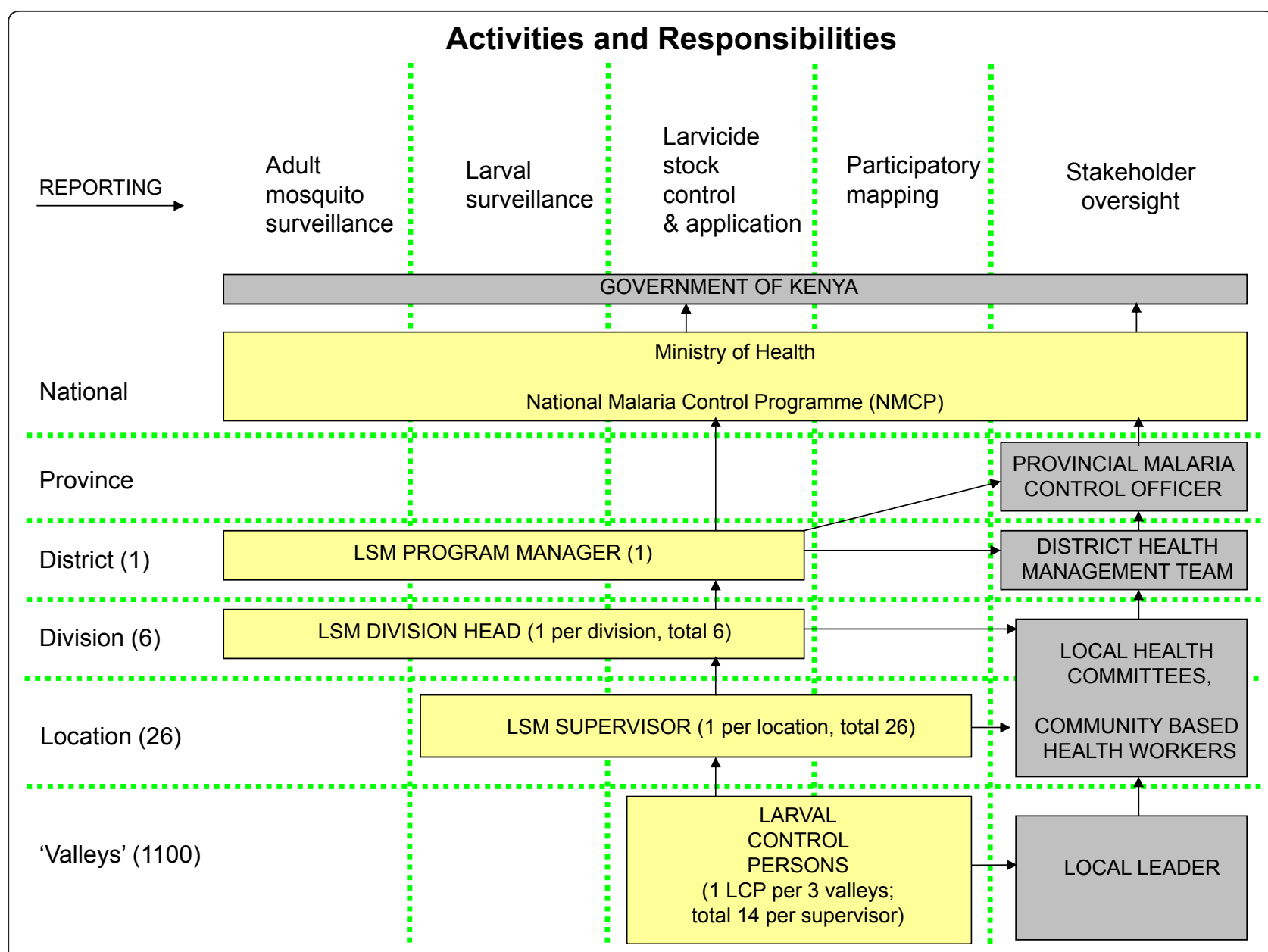

Figure 2 Model programme structure for a LSM programme in the highland valleys of Vihiga District, western Kenya.

Scenario 1 - use of WG formulation for liquid application;

Scenario 2 - use of CG formulation for hand application.

The type of formulation used affects product storage, associated equipment and shipping costs. The implications of changes in the larvicide product price in both of these scenarios were also examined. In Dar es Salaam larvicide product use was based on actual usage of a combination of WG and CG products, therefore a scenario analysis was not carried out however we did look at the implications of changes in larvicide product prices.

\section{Results}

Dar es Salaam, Tanzania

Model programme structure, staffing and training

The proposed programme structure for a LSM programme covering 15 city wards ( 5 per municipality) is shown in Figure 1. Table 2 lists the staff required and their responsibility in the programme. The programme is overseen by a programme manager who is directly responsible to the City Medical Officer and the NMCP. The manager is assisted in the daily work by two surveillance officers. Each of the three municipalities in Dar es Salaam has a malaria control coordinator that will ensure quality work implemented on ward level. Two inspectors per municipality will implement quality control and help with training activities. Each ward will have a supervisor overseeing the work of community-based resource persons (CORPs) involved in larval surveillance and larviciding. Two larval surveillance CORPs per ward will be responsible for habitat spot checks to ensure that larval habitats are treated in a timely manner and the larvicide is working. The number of LCPs was calculated based on the area one person can cover per week $(0.2-1.5 \mathrm{~km} 2)$ [34]. Technical assistance from an academic partner was assumed to be required for the equivalent of three months per annum. Support staff included three full time drivers for transporting staff and equipment, an administrator and general hand. 


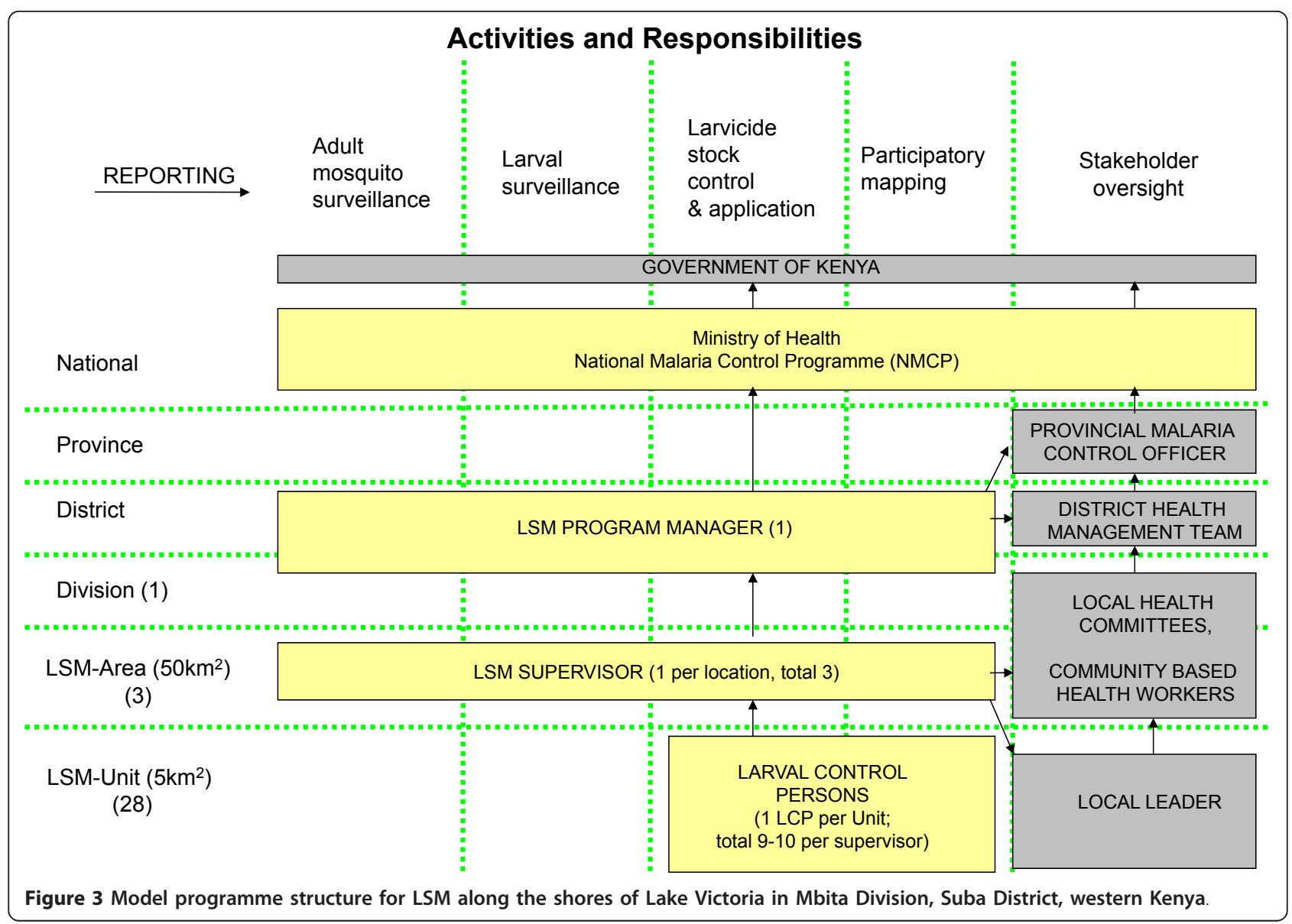

It was assumed that the city and municipal level staff would receive specific training and support as required by the external technical adviser. These would then train other team members with support from the external technical adviser if required, e.g. inspectors and supervisors would train the LCPs. It was estimated that 135 LCPs and surveillance CORPs would need to be trained to provide sufficient coverage for the programme and allow for some attrition during training. LCPs would be trained prior to official recruitment and would, therefore, be paid a daily wage for training plus an allowance for transportation and lunch. Four six-day training sessions were calculated to be needed and a training room would need to be rented. Training would need to be repeated on an annual basis to account for attrition of staff and to adapt and improve programme delivery.

Larvicide, protective clothing, and application equipment

The quantity of larvicide required for 15 city wards was based on the actual use of VectoBac ${ }^{\mathbb{B}}$ (CG and WG formulations) per $\mathrm{km}^{2}$ from the three UMCP intervention wards in 2006. Calculations were based on the assumption that the CG formulation would be used for the majority of habitats since many of the aquatic sites are densely vegetated and can only be penetrated by granule. Furthermore, hand application is less prone to technical problems and was, therefore, chosen for the application of larvicides with CORPs in Dar es Salaam [26]. Nevertheless, large open water bodies can be more efficiently treated using liquid application with knapsack sprayers and therefore a budget is required for smaller quantities of WG formulations and application equipment. However, in order to enable comparison between similar programmes in the different locations the programme were all costed using CG formulation. As CG is the more expensive product this will if anything slightly increase the estimated cost of the programme. However the cost of equipment (30 Hudson spray pumps) needed to deliver the WG formulation was included as well as granule blowers (6) to allow treatment of large water surface areas with CG. More detail on product properties and decision-making processes for LSM programmes can be found elsewhere [26,27,49].

The intervention consisted of weekly treatment of all open (as opposed to closed, underground water e.g. septic tanks, latrines) water bodies within the 15 wards. 
Table 2 Staff structure of model LSM program for 15 city wards of Dar es Salaam

\begin{tabular}{|c|c|c|c|}
\hline $\begin{array}{l}\text { Administrative } \\
\text { level }\end{array}$ & Staff & $\begin{array}{l}\text { Time or number of } \\
\text { staff required }\end{array}$ & Role \& responsibility \\
\hline \multicolumn{4}{|c|}{ PART TIME STAFF CONTRIBUTION TO PROGRAM } \\
\hline International & LSM expert & 3 months/year & $\begin{array}{l}\text { Advice on technical and programme management. Capacity building, support and } \\
\text { trouble shooting. }\end{array}$ \\
\hline \multirow[t]{2}{*}{ National } & Director of NMCP & 1 hour/week & Approval of programme, reading progress reports, site visits. \\
\hline & Procurement Officer & 1 week/year & Central procurement of larvicide and equipment \\
\hline Regional & City Medical Officer & 1 week/year & Approval of programme, reading progress reports, signing documents, site visits. \\
\hline \multicolumn{4}{|c|}{ FULL TIME PROGRAM STAFF } \\
\hline \multirow[t]{8}{*}{ Regional } & $\begin{array}{l}\text { City Program } \\
\text { Manager }\end{array}$ & 1 & $\begin{array}{l}\text { Day to day programme management, financial management. Recruiting and training } \\
\text { Divisional Heads }\end{array}$ \\
\hline & $\begin{array}{l}\text { City Surveillance } \\
\text { Officer }\end{array}$ & 2 & $\begin{array}{l}\text { Assisting programme manager in field supervision of activities, training, community } \\
\text { sensitization, supervision of adult vector monitoring, reports. }\end{array}$ \\
\hline & $\begin{array}{l}\text { Adult mosquito } \\
\text { surveillance officer }\end{array}$ & 1 & Laboratory identification of adult mosquitoes \\
\hline & $\begin{array}{l}\text { City Mapping } \\
\text { Officer }\end{array}$ & $1^{*}$ & Mapping of target area \\
\hline & Mapping Technician & $1^{*}$ & Mapping of target area \\
\hline & Driver & 3 & Transporting staff and equipment \\
\hline & Administrator & 1 & Support to programme management and finance \\
\hline & General hand & 1 & Support to office staff \\
\hline \multirow[t]{2}{*}{$\begin{array}{l}\text { Municipal/ } \\
\text { District }\end{array}$} & $\begin{array}{l}\text { Municipal } \\
\text { Coordinator }\end{array}$ & 3 & Program oversight at municipal level, review of data sheets, report writing \\
\hline & Municipal Inspectors & 6 & Supervision and training of field staff, weekly reports. \\
\hline Ward & Ward Supervisor & 15 & $\begin{array}{l}\text { Supervision of larval survey CORPs and LCPs, distribution of larvicides, collation of } \\
\text { field data, weekly reports }\end{array}$ \\
\hline \multirow[t]{2}{*}{ TCU } & Larval Surveillance & 30 & Larval Habitat Spot Checks, reporting to supervisor. \\
\hline & Larval Control & 89 & $\begin{array}{l}\text { Treating breeding sites with larvicide, reporting to supervisor, collecting larvicide } \\
\text { from store }\end{array}$ \\
\hline
\end{tabular}

* These salaries are treated as a capital cost because the detailed mapping is only required once.

Application and larval monitoring equipment requirements, including protective clothing were calculated according to the number of larval surveillance CORPs and LCPs employed. Itemized recurrent unit costs, useful life and capital costs are provided in Additional file 2 .

\section{Operations costs and overheads}

Office and storage space requirements were calculated according to the number of staff and the volume of product and equipment that would be required at city and municipal levels. Overheads, such as utilities, insurance, and security, were considered along with other office support requirements, such as stationary, printing, photocopying, and communication (e.g. internet, telephone, and mobile telephones). Equipment, such as computers, printers, and global positioning system (GPS) units for mapping, was also included.

\section{Transport and vehicles}

Two project vehicles were required by the UMCP programme manager and the city malaria surveillance officers. The vehicles were also needed to transport the larvicide and equipment to the municipal areas. The municipal malaria control coordinators and inspectors used motorbikes to coordinate and supervise additional wards. Insurance, servicing, and fuel requirements were calculated based on UMCP data. Ward supervisors were not given vehicles, but instead were provided with a transportation allowance so they could use public transport around their area of responsibility and for staff meetings.

\section{Adult mosquito monitoring}

At the time of costing this programme, no traps were available to monitor the low density of vectors in the urban setting [26]. Therefore, human-landing catches were included as monitoring and evaluation tool here since this was the standard collection technique at the time. Nevertheless, it is expected that this tool will be replaced in the UMCP in the near future with the Ifakara Tent Trap which will be safer for the human bait, more efficient and cheaper than human-landing catches $[50,51]$. Allowances to community members for taking part in human landing catch surveys were calculated by assuming that there would be one person per mitaa (neighbourhood; there were 67 in the target area) for one night per week. Field equipment to collect mosquitoes (e.g. cups, gauzes and cool boxes), a microscope, 
light source, and adult surveillance officer/laboratory technicians' time were also included. Full details of the assumptions regarding recurrent and capital inputs and unit costs are provided in Additional File 2.

\section{Dar es Salaam costing results}

Table 3 shows the summary of the costing. The total annual cost of the programme was estimated at US\$559, 476 to cover 592, 338 people located over $58 \mathrm{~km} 2$. Consequently, we estimate the cost per person protected to be US $\$ 0.94$. Recurrent costs comprise $97 \%$ of the total programme costs. Cost, insurance, and freight (CIF) of the larvicide and protective clothing comprise $34 \%$ and programme staff salaries $31 \%$ of the total costs. Community sensitization (i.e. community education and briefing on programme activities) has a relatively high proportion of costs $(9 \%)$ compared to the other programmes costed. Staff of the UMCP emphasized the importance of such communication tools in the urban setting. The printing and distribution of leaflets to households is crucial to ensure access to plots on treatment days. Taking the lowest and highest values of the published prices for VectoBac ${ }^{\circledR}$ altered the cost per person protected to US $\$ 0.90$ and US\$0.98 respectively. At the lowest and highest prices for each product, the total programme costs are US\$530, 866 and US\$578, 262, respectively.

\section{Vihiga District, western Kenya Highlands} Model programme structure, staffing and training

To plan the intervention, the district was divided into small manageable units. Because of the nature of the intervention and the topography of the district, these units are based on ecological rather than administrative zones. In a previous LSM project that informed this model structure, intervention areas were defined as

Table 3 LSM in urban Dar es Salaam: Financial and economic costs for 15 city wards (in US\$ 2006 at midpoint larvicide price)

\begin{tabular}{|c|c|c|c|c|c|c|c|c|}
\hline \multirow[t]{2}{*}{ Cost category } & \multicolumn{2}{|c|}{$\begin{array}{l}\text { Pre-implementation } \\
\text { Costs (Y0) Total: }\end{array}$} & \multicolumn{2}{|c|}{$\begin{array}{l}\text { Implementation Year } \\
\text { Costs (Y1) Total: }\end{array}$} & \multicolumn{2}{|c|}{ Average Annual Costs: } & \multicolumn{2}{|c|}{ Proportion of Total Average: } \\
\hline & $\begin{array}{l}\text { Financial } \\
\text { Cost }\end{array}$ & $\begin{array}{l}\text { Economic } \\
\text { Cost }\end{array}$ & $\begin{array}{l}\text { Financial } \\
\text { Cost }\end{array}$ & $\begin{array}{l}\text { Economic } \\
\text { Cost }\end{array}$ & $\begin{array}{l}\text { Financial } \\
\text { Cost }\end{array}$ & $\begin{array}{l}\text { Economic } \\
\text { Cost }\end{array}$ & $\begin{array}{c}\text { Annual } \\
\text { Financial Cost }\end{array}$ & $\begin{array}{c}\text { Annual } \\
\text { Economic Cost }\end{array}$ \\
\hline \multicolumn{9}{|l|}{ RECURRENT COSTS } \\
\hline International staff costs & 30028.0 & 30028.0 & 30028.0 & 30028.0 & 33781.5 & 33952.2 & 0.05 & 0.06 \\
\hline NMCP/MoH staff costs & 0.0 & 46.1 & 0.0 & 46.1 & 0.0 & 52.1 & 0 & 0 \\
\hline Program staff salaries & 40349.5 & 34801.5 & 193569.0 & 166953.2 & 198612.6 & 171501.2 & 0.3 & 0.31 \\
\hline $\begin{array}{l}\text { Larvicide (CIF) } \\
\text { protective clothes }\end{array}$ & 1500.0 & 1500.0 & 237771.2 & 191480.8 & 237958.7 & 191676.8 & 0.36 & 0.34 \\
\hline Staff Training & 0.0 & 0.0 & 4724.9 & 3779.9 & 4724.9 & 3779.9 & 0.01 & 0.01 \\
\hline $\begin{array}{l}\text { Community } \\
\text { sensitization }\end{array}$ & 0.0 & 0.0 & 66083.1 & 52866.5 & 66083.1 & 52866.5 & 0.1 & 0.09 \\
\hline $\begin{array}{l}\text { Operations costs and } \\
\text { overheads }\end{array}$ & 39743.1 & 31794.5 & 46880.1 & 37504.1 & 51848.0 & 41659.1 & 0.08 & 0.07 \\
\hline Transport & 11456.8 & 9165.5 & 37279.8 & 30430.2 & 38711.9 & 31628.0 & 0.06 & 0.06 \\
\hline $\begin{array}{l}\text { Adult mosquito } \\
\text { monitoring }\end{array}$ & 17772.5 & 15297.7 & 17772.5 & 15297.7 & 19994.0 & 17296.8 & 0.03 & 0.03 \\
\hline \multicolumn{9}{|l|}{ CAPITAL COSTS } \\
\hline $\begin{array}{l}\text { Mapping area/breeding } \\
\text { sites }\end{array}$ & 965.9 & 1039.5 & 965.9 & 1039.5 & 1086.6 & 1175.3 & 0 & 0 \\
\hline $\begin{array}{l}\text { Storage space and } \\
\text { equipment }\end{array}$ & 0.0 & 0.0 & 375.4 & 295.4 & 375.4 & 295.4 & 0 & 0 \\
\hline Vehicles & 4664.7 & 4074.0 & 8396.4 & 7239.8 & 8979.5 & 7772.2 & 0.01 & 0.01 \\
\hline Spray pumps & 1807.9 & 1578.9 & 1807.9 & 1578.9 & 2033.9 & 1785.3 & 0 & 0 \\
\hline $\begin{array}{l}\text { Computers and other } \\
\text { equipment }\end{array}$ & 4090.0 & 3466.8 & 4090.0 & 3466.8 & 4601.3 & 3919.8 & 0.01 & 0.01 \\
\hline $\begin{array}{l}\text { Adult monitoring } \\
\text { equipment }\end{array}$ & 400.0 & 349.3 & 400.0 & 69.9 & 450.0 & 115.5 & 0 & 0 \\
\hline $\begin{array}{l}\text { SUBTOTAL RECURRENT } \\
\text { COSTS }\end{array}$ & 140850.0 & 122633.2 & 634108.4 & 528386.4 & 651714.7 & 544412.7 & 0.97 & 0.97 \\
\hline SUBTOTAL CAPITAL COSTS & 11928.5 & 10508.5 & 16035.6 & 13690.3 & 17526.7 & 15063.6 & 0.03 & 0.03 \\
\hline TOTAL COSTS OF PROGRAM & 152778.4 & 133141.7 & 650144.0 & 542076.7 & 669241.4 & 559476.3 & 1 & 1 \\
\hline $\begin{array}{l}\text { COST PER PERSON } \\
\text { PROTECTED }\end{array}$ & 0.26 & 0.22 & 1.1 & 0.92 & 1.13 & 0.94 & & \\
\hline
\end{tabular}


ecological valleys (for details see [28]). Six valleys in Vihiga District correspond to the equivalent of approximately one sub-location (a Kenyan administrative unit below the location level). It was, therefore, generously estimated that throughout the whole district, each sublocation would contain ten ecological valleys. Using this unit and based on experience from the research project, we estimated the amount of resources that would be required to treat all breeding sites in the valley bottom and up the sides of the valleys at weekly intervals. Given the seasonal nature of peak vector densities in Vihiga District and increasing coverage with LLINs year round larviciding is not necessary [28]. The programme was developed around an intervention period beginning in February and ending in May. This 16-week period begins at the end of the dry season and continues throughout the long rainy season.

Based on experience, it was assumed that one person could treat all breeding sites within a valley in one day, and each LCP was given responsibility for three valleys. LCPs would be recruited from the local community thus maximizing local knowledge of potential sites, increasing local acceptance for the programme, and contributing to the local economy and LSM programme sustainability. This approach also has the advantage of reducing the need to transport LCPs around the district, thus minimizing transport costs. Although the intervention was assumed to last 16 weeks, costs were generously estimated based on employing LCPs for 18 weeks, not including training time which is captured under staff training. Therefore, it was estimated that 367 LCPs would be required in the whole Vihiga District. LCPs would be paid a daily wage for three days per week, plus one day's transportation allowance for collecting the larvicide from the divisional level storage location (see below). Support staff included a year round full time driver and an administrative assistant for the six month intervention phase.

LCPs were divided into 26 teams based on the number of locations in the district. Each team of LCPs would be managed by a supervisor who would be responsible for overseeing an average of 14 LCPs. It was assumed that supervisors would also be from the location which they managed and that they would take responsibility for working with the community to select LCPs. Given that the supervisors would need to be trained prior to recruiting the LCPs, it was assumed that they would be employed and paid a monthly wage for six months.

Six divisional heads (recruited and trained during the pre-intervention phase) would be responsible for managing and supervising activities within their respective divisions. Divisional heads would be full time staff paid an annual salary in order to prepare for the intervention phase, manage it, and then participate in evaluation and modification of the programme before the subsequent year's intervention. A programme manager would also be paid a full time annual salary to manage and oversee the programme. The team would be supported by a driver throughout the year and an administrative assistant employed for six months a year. It was also assumed that international experts would provide support to the programme for five months a year (some remote and some on site), although such high commitment would only be required at the start up of a new programme in the first $11 / 2$ years. All individuals described above would need to be recruited by the programme and would spend all of their time during employment working on the larval control intervention. The opportunity cost of existing $\mathrm{MoH}$ employees, who would need to allocate some of their time to the programme, were also considered implicitly assuming the spare capacity of these individuals. The level of involvement that would be required from the Director of the NMCP, the NMCP entomologist, central level procurement officer, provincial level malaria control officer, district level public health officer, and district medical officer was estimated. Table 4 provides a summary of the personnel requirements for new project staff and existing $\mathrm{MoH}$ staff who would contribute a portion of their time to the programme.

It was assumed that the programme manager would be a biological science graduate and be trained by the international expert in programme management. The programme manager and international expert would then recruit and train the divisional heads. A one-week trip to visit the operational LSM programme in Dar es Salaam, Tanzania was also incorporated for the programme manager and divisional heads as part of in-service training. Once recruited, it was assumed that supervisors would be trained by divisional heads. Supervisors and divisional heads would then train the LCPs. It was assumed that $420 \mathrm{LCPs}$ would be trained to provide sufficient coverage for the programme and allow for some attrition during training. LCPs would be trained prior to recruitment and would, therefore, be paid a daily wage for training, plus an allowance for transportation and lunch. It was calculated that 12 sixday training sessions would be needed with 35 LCPs per course. The assumption was made that training would take place in the intervention sites and in locations where communities usually meet (i.e. outdoor locations that do not require rental of space). Training would need to be repeated on an annual basis to account for staff attrition staff.

\section{Larvicide product, protective clothing, and application equipment}

The quantity of larvicide required was based on usage of VectoBac ${ }^{\circledR}$ in a previous LSM project implemented 
Table 4 Staff structure of model LSM program for Vihiga District, Kenya

\begin{tabular}{|c|c|c|c|c|}
\hline $\begin{array}{l}\text { Administrative } \\
\text { level }\end{array}$ & \multicolumn{2}{|c|}{ Number of staff } & $\begin{array}{c}\text { Time } \\
\text { contributed/ } \\
\text { period } \\
\text { employed per } \\
\text { year }\end{array}$ & Role \& responsibility \\
\hline \multicolumn{5}{|c|}{ Part time staff contribution to program } \\
\hline International & LSM expert & 1 & 5 months & $\begin{array}{l}\text { Advice on technical and programme management. Capacity building, support and } \\
\text { trouble shooting. }\end{array}$ \\
\hline \multirow[t]{3}{*}{ National } & $\begin{array}{l}\text { Director } \\
\text { NMCP }\end{array}$ & 1 & 1 week & Approval of programme, reading progress reports, signing documents, site visits. \\
\hline & Entomologist & 1 & 1 week & Reading progress reports, technical advice, site visits. \\
\hline & $\begin{array}{l}\text { Procurement } \\
\text { Officer }\end{array}$ & 1 & 1 week & Central procurement of larvicide and equipment \\
\hline Provincial & $\begin{array}{l}\text { Malaria } \\
\text { Control } \\
\text { Officer }\end{array}$ & 1 & 1 week & Engagement in stakeholder meetings. Site visits with NMCP staff. \\
\hline \multirow[t]{2}{*}{ District } & $\begin{array}{l}\text { Public Health } \\
\text { Officer }\end{array}$ & 1 & 1 hour/week & Involvement in weekly management meetings. \\
\hline & $\begin{array}{l}\text { Medical } \\
\text { Officer }\end{array}$ & 1 & 2.5 weeks & Involvement in weekly management meetings, sensitization of District health staff. \\
\hline \multicolumn{5}{|c|}{ Full time program staff } \\
\hline \multirow[t]{3}{*}{ District } & $\begin{array}{l}\text { Program } \\
\text { manager }\end{array}$ & 1 & 12 months & $\begin{array}{l}\text { Day to day programme management, financial management. Recruiting and training } \\
\text { Divisional Heads. }\end{array}$ \\
\hline & Driver & 1 & 12 months & Transport of programme manager, transport of equipment and supplies \\
\hline & $\begin{array}{l}\text { Admin. } \\
\text { assistant }\end{array}$ & 1 & 6 months & $\begin{array}{l}\text { Administrative duties during intervention and for one month during pre and post } \\
\text { intervention phase }\end{array}$ \\
\hline Division & $\begin{array}{l}\text { Divisional } \\
\text { Heads }\end{array}$ & 6 & 12 months & $\begin{array}{l}\text { Field work management, quality control, adult mosquito monitoring, reporting to } \\
\text { programme manager. Evaluation and planning subsequent year's intervention. Training of } \\
\text { Supervisors and LCP. }\end{array}$ \\
\hline Location & Supervisors & 26 & 6 months & Recruitment and supervision of LCP, larval habitat spot checks. \\
\hline Valleys & LCP & 367 & 18 weeks & $\begin{array}{l}\text { Treating breeding sites with larvicide, reporting to supervisors, collecting larvicide from } \\
\text { divisional store. }\end{array}$ \\
\hline
\end{tabular}

in 3 valleys of Vihiga District [28]. Mean monthly usage was calculated from the three sites and multiplied by the number of valleys in the district to obtain the total amount required to treat the whole district. The implications of using the two alternative formulations in terms of transport, storage, and equipment requirements were captured as follows. If only WG formulation would be used 400 Hudson spray pumps would be required (one per LCP and some spares to account for loss through breakage and theft). CG granule is applied by hand and we included buckets or backpacks as carriage containers instead of sprayers. Other field equipment that is required independently from the formulation used e.g. protective clothing for LCPs, was itemized. For both scenarios, we considered shipping the product from the U.S. to Mombasa (including insurance), port clearance fees, and ground transport from Mombasa to Vihiga District, based on the required volume and weight of the product. Storage and distribution of the product once arrived at the district level was considered under operations costs and overheads (see below).

\section{Operations costs and overheads}

A furnished office would be needed all year at the district level, including insurance, utilities, and a security guard. The amount of storage space required was estimated to keep each of the alternative larvicide formulations and other equipment at the district level in secure metal containers. It was assumed that five additional furnished offices with storage space would be required at the divisional levels for six months each year. Insurance, utilities, and security guards for these offices were also included. A truck and driver would need to be hired for one day per month if WG formulation was used and two days per month if CG formulation was used during the four-month intervention period to transport the larvicide from the district to the divisional offices. Transport of the product from the divisional offices to the intervention valleys would be done on a weekly basis by LCPs, who would be given a travel allowance equivalent to one day's wage, to do this in whatever way they chose. Appropriate staff was allocated a mobile phone and monthly communication allowance to purchase phone credits for the duration of their 
employment. Computers, printers, GPS units, and Internet connectivity were also considered along with requisite software. Stationary, printing, and photocopying requirements were captured.

\section{Transport and vehicles}

A quote for a suitable project vehicle was obtained from a local supplier. Data on fuel, insurance, servicing, and repair requirements for a similar vehicle used in same area were obtained from Kenya Medical Research Institute (KEMRI) records. Divisional heads would each need a motorbike, including fuel, insurance, and maintenance. Given the relatively large distances to be covered by the LCPs, it was assumed that each would be furnished with a bicycle. This was treated as a recurrent cost because it was assumed that after one year, the bicycles would be given to the LCP. In return, the LCP would be responsible for maintenance and repair of the bicycles during the intervention and would have an incentive to take care of them.

\section{Adult mosquito monitoring}

Adult mosquito monitoring would be required year round in a stratified sample of approximately 117 houses within each division (approx. 1 collection site/ $\mathrm{km}^{2}$ ) to monitor effectiveness of the programme during the intervention period. It was also considered necessary to maintain this monitoring throughout the year to ensure that the intervention was appropriately targeted in time. This activity would be carried out by the divisional heads using locally produced clay pots, which have been shown to provide effective outdoor catches for adult mosquitoes [52]. A microscope and light source, as well as other supplies, including ethanol, vials, Petri dishes, and dissecting kits, would be required for this activity. Mosquito identification would be done by the programme manager with assistance of Division heads. Full details of the assumptions regarding recurrent and capital inputs and unit costs are provided in the Additional File 3.

\section{Vihiga District costing results}

Table 5 shows the results of the costing considerations for Scenario 1 - WG use only. The cost per person protected using the WG larvicide formulation was US\$0.79, and the total annual programme costs were estimated at US\$480, 735 to cover 609 , 324 people located over 563 $\mathrm{km} 2$. Recurrent costs make up $94 \%$ of total costs. A fifth of total cost is allocated to programme staff salaries. Operations costs and overheads contribute 13\% of programme costs. CIF of the larvicide and protective clothing make up almost half (47\%) of total programme costs.

Taking the lowest value of the published prices for VectoBac ${ }^{\circledR}$ WG reduced the economic cost of the programme to US $\$ 437,753$ and the cost per person protected falls to $\$ 0.72$. Taking the highest published price for VectBac ${ }^{\circledR}$ increases the total programme costs to US $\$ 511,306$ and the costs per person protected increases by $\$ 0.05$ to US $\$ 0.84$.

Table 6 shows the results of the costing considerations for Scenario 2 - CG use only. At midpoint prices, the economic cost per person protected is US\$1.50. The total programme costs are US\$916, 908. In this scenario, CIF of the larvicide and protective clothing make up around two thirds of programme costs (67\%). Taking the lowest value of CG prices reduced the cost per person to US $\$ 1.35$ and the total programme costs to US $\$ 823,668$. Taking the highest published price increases the total programme costs to US\$978, 130 and the cost per person protected increases to US\$1.61.

\section{Mbita Division, Suba District, shores of Lake Victoria, western Kenya \\ Model programme structure, staffing and training}

Given the perennial nature and heterogeneity of malaria transmission in Mbita Division and the predominance of people-made habitats, year round larviciding was assumed necessary to control malaria vectors in this location [14]. The amount of resources that would be required to treat all breeding sites in $140 \mathrm{~km}^{2}$ of Mbita Division on a weekly basis, year round based was estimated based on data available from a previous small scale LSM project [27]. The model programme structure is shown in Figure 3.

One locally-recruited LCP would be required to treat all breeding sites in one $\mathrm{km}^{2}$ each per day. Each LCP would therefore be given an area of five $\mathrm{km}^{2}$ to treat each week. To cover the total area, 28 LCPs would be required. Supervisors would monitor the work of the LCPs and carry out larval spot checks. Three supervisors would be required and each would be responsible for nine to ten LCPs and approximately $47 \mathrm{~km}^{2}$ of land. One programme manager would be required to oversee the programme, along with a driver. All staff would be employed year round and would spend all their time during employment working on the larval control intervention.

The opportunity costs of existing $\mathrm{MoH}$ employees who would need to allocate some of their time to the programme were also considered. The level of involvement that would be required from the provincial malaria control officer, district level public health officer, and DMO were estimated. International expert support was included for two months per year. Table 7 provides a summary of personnel requirements for both full time project staff and existing staff who would contribute a portion of their time to the programme.

Assumption was that the programme manager would be a postgraduate in biological sciences and be trained by the international expert in larval programme management. The programme manager and international 
Table 5 LSM in western Kenya highlands - Vihiga District: Scenario 1 - Financial and economic costs using VectoBac WG formulation (in US\$ $\mathbf{2 0 0 6}$ at midpoint larvicide price)

\begin{tabular}{|c|c|c|c|c|c|c|c|c|}
\hline \multirow[t]{2}{*}{ Cost category } & \multicolumn{2}{|c|}{$\begin{array}{l}\text { Pre-implementation } \\
\text { Costs (Y0) Total: }\end{array}$} & \multicolumn{2}{|c|}{$\begin{array}{l}\text { Implementation Year } \\
\text { Costs (Y1) Total: }\end{array}$} & \multicolumn{2}{|c|}{ Average Annual Costs: } & \multicolumn{2}{|c|}{ Proportion of Total Average: } \\
\hline & $\begin{array}{l}\text { Financial } \\
\text { Cost }\end{array}$ & $\begin{array}{l}\text { Economic } \\
\text { Cost }\end{array}$ & $\begin{array}{l}\text { Financial } \\
\text { Cost }\end{array}$ & $\begin{array}{l}\text { Economic } \\
\text { Cost }\end{array}$ & $\begin{array}{l}\text { Financial } \\
\text { Cost }\end{array}$ & $\begin{array}{l}\text { Economic } \\
\text { Cost }\end{array}$ & $\begin{array}{c}\text { Annual } \\
\text { Financial Cost }\end{array}$ & $\begin{array}{c}\text { Annual } \\
\text { Economic Cost }\end{array}$ \\
\hline \multicolumn{9}{|l|}{ RECURRENT COSTS } \\
\hline International staff costs & 23013.0 & 23013.0 & 34665.0 & 34665.0 & 37541.7 & 37672.5 & 0.07 & 0.08 \\
\hline NMCP/MoH staff costs & 0.0 & 0.0 & 0.0 & 826.3 & 0.0 & 826.3 & 0 & 0 \\
\hline $\begin{array}{l}\text { Programme staff } \\
\text { salaries }\end{array}$ & 11484.6 & 9848.0 & 110894.0 & 95091.6 & 112329.5 & 96378.6 & 0.22 & 0.2 \\
\hline $\begin{array}{l}\text { Larvicide (CIF), } \\
\text { protective cloth }\end{array}$ & 0.0 & 0.0 & 230775.3 & 226247.4 & 230775.3 & 226247.4 & 0.44 & 0.47 \\
\hline Staff Training & 0.0 & 0.0 & 12820.4 & 10769.2 & 12820.4 & 10769.2 & 0.02 & 0.02 \\
\hline $\begin{array}{l}\text { Community } \\
\text { sensitization }\end{array}$ & 0.0 & 0.0 & 68.9 & 57.8 & 68.9 & 57.8 & 0 & 0 \\
\hline $\begin{array}{l}\text { Operations costs and } \\
\text { overheads }\end{array}$ & 1985.5 & 1667.8 & 75984.8 & 63827.3 & 76233.0 & 64045.2 & 0.15 & 0.13 \\
\hline Transport & 6324.8 & 5312.9 & 14081.8 & 11828.7 & 14872.4 & 12523.1 & 0.03 & 0.03 \\
\hline $\begin{array}{l}\text { Adult mosquito } \\
\text { monitoring }\end{array}$ & 799.8 & 671.8 & 1599.6 & 1343.7 & 1699.6 & 1431.5 & 0 & 0 \\
\hline \multicolumn{9}{|l|}{ CAPITAL COSTS } \\
\hline Maps & 66.7 & 83.8 & 66.8 & 83.8 & 75.0 & 94.8 & 0 & 0 \\
\hline Vehicles & 5095.1 & 4636.2 & 10190.3 & 9272.5 & 10827.2 & 9878.4 & 0.02 & 0.02 \\
\hline Spray pumps & 0.0 & 0.0 & 20000.0 & 18340.6 & 20000.0 & 18340.6 & 0.04 & 0.04 \\
\hline $\begin{array}{l}\text { Computers, other } \\
\text { equipment }\end{array}$ & 871.7 & 774.9 & 2330.0 & 2072.4 & 2439.0 & 2173.6 & 0 & 0 \\
\hline $\begin{array}{l}\text { Adult monitoring } \\
\text { equipment }\end{array}$ & 200.0 & 183.4 & 400.0 & 366.8 & 425.0 & 390.8 & 0 & 0 \\
\hline $\begin{array}{l}\text { SUBTOTAL RECURRENT } \\
\text { COSTS }\end{array}$ & $43,607.8$ & $40,513.6$ & $480,889.8$ & $444,656.9$ & $486,340.7$ & $449,951.4$ & 0.94 & 0.94 \\
\hline SUBTOTAL CAPITAL COSTS & $6,166.8$ & $5,594.5$ & $32,920.3$ & $30,052.3$ & $33,691.1$ & $30,783.4$ & 0.06 & 0.06 \\
\hline TOTAL PROGRAM COST & $49,774.5$ & $46,108.1$ & $513,810.0$ & $474,709.1$ & $520,031.9$ & $480,734.7$ & 1 & 1 \\
\hline $\begin{array}{l}\text { COST PER PERSON } \\
\text { PROTECTED }\end{array}$ & 0.08 & 0.08 & 0.84 & 0.78 & 0.85 & 0.79 & & \\
\hline
\end{tabular}

expert would then recruit and train the supervisors. A one-week trip to visit an operational larval control programme in Tanzania for the programme manager and supervisors as part of in-service training was costed. Supervisors would train 35 LCPs, which would provide sufficient coverage for the programme and allow for some attrition during/after training. LCPs would be trained prior to recruitment and would, therefore, be paid a daily wage for training, plus an allowance for transportation and lunch. One six-day training session would be needed. Training would take place in the intervention sites and in locations where communities usually meet (i.e., outdoors locations that do not require rental of space). Training would need to be repeated on an annual basis to account for staff attrition.

\section{Larvicide product, protective clothing, and application} equipment

Mean monthly usage of VectoBac ${ }^{\circledR}$ in kilograms per $\mathrm{km} 2$ of land and water surface area treated was calculated based on usage in a previous LSM project implemented in Mbita town for over two years[27]. The implications of using the two alternative formulations in terms of transport, storage, and equipment requirements were captured in a similar way as for Vihiga District. Protective clothing and other equipment requirements were calculated according to the number of LCPs operating. The product would be shipped from the U.S. to Mombassa (including insurance). Port clearance fees, and ground transport from Mombassa to Mbita, based on the required volume and weight of the product were costed.

\section{Operations costs and overheads}

Office and storage space rental at the divisional level was captured in the same way as for Vihiga District. Communication costs, including mobile phones, phone usage credit, and Internet access, were accounted for. Office equipment, including a computer, printer, stationary, and printing requirements, were also included. 
Table 6 LSM in western Kenya highlands - Vihiga District: Scenario 2 - Financial and economic costs using VectoBac CG formulation (in US\$ 2006 at midpoint larvicide price)

\begin{tabular}{|c|c|c|c|c|c|c|c|c|}
\hline \multirow[t]{2}{*}{ Cost category } & \multicolumn{2}{|c|}{$\begin{array}{l}\text { Pre-implementation } \\
\text { Costs (Y0) Total: }\end{array}$} & \multicolumn{2}{|c|}{$\begin{array}{l}\text { Implementation Year } \\
\text { Costs (Y1) Total: }\end{array}$} & \multicolumn{2}{|c|}{ Average Annual Costs: } & \multicolumn{2}{|c|}{ Proportion of Total Average: } \\
\hline & $\begin{array}{l}\text { Financial } \\
\text { Cost }\end{array}$ & $\begin{array}{l}\text { Economic } \\
\text { Cost }\end{array}$ & $\begin{array}{l}\text { Financial } \\
\text { Cost }\end{array}$ & $\begin{array}{l}\text { Economic } \\
\text { Cost }\end{array}$ & $\begin{array}{l}\text { Financial } \\
\text { Cost }\end{array}$ & $\begin{array}{l}\text { Economic } \\
\text { Cost }\end{array}$ & $\begin{array}{c}\text { Annual } \\
\text { Financial Cost }\end{array}$ & $\begin{array}{c}\text { Annual } \\
\text { Economic Cost }\end{array}$ \\
\hline \multicolumn{9}{|l|}{ RECURRENT COSTS } \\
\hline International staff costs & 23013.0 & 23013.0 & 34665.0 & 34665.0 & 37541.7 & 37672.5 & 0.04 & 0.04 \\
\hline NMCP/MoH staff costs & 0.0 & 0.0 & 0.0 & 60001.1 & 0.0 & 60001.1 & 0 & 0.07 \\
\hline $\begin{array}{l}\text { Programme staff } \\
\text { salaries }\end{array}$ & 11484.6 & 9848.0 & 110894.0 & 95091.6 & 112329.5 & 96378.6 & 0.12 & 0.11 \\
\hline $\begin{array}{l}\text { Larvicide (CIF), } \\
\text { protective cloth }\end{array}$ & 0.0 & 0.0 & 625985.3 & 616959.8 & 625985.3 & 616959.8 & 0.69 & 0.67 \\
\hline Staff Training & 0.0 & 0.0 & 12820.4 & 10769.2 & 12820.4 & 10769.2 & 0.01 & 0.01 \\
\hline $\begin{array}{l}\text { Community } \\
\text { sensitization }\end{array}$ & 0.0 & 0.0 & 68.9 & 57.8 & 68.9 & 57.8 & 0 & 0 \\
\hline $\begin{array}{l}\text { Operations costs and } \\
\text { overheads }\end{array}$ & 1985.5 & 1667.8 & 81493.1 & 68454.2 & 81741.3 & 68672.1 & 0.09 & 0.07 \\
\hline Transport & 6324.8 & 5312.9 & 14081.8 & 11828.7 & 14872.4 & 12523.1 & 0.02 & 0.01 \\
\hline $\begin{array}{l}\text { Adult mosquito } \\
\text { monitoring }\end{array}$ & 799.8 & 671.8 & 1599.6 & 1343.7 & 1699.6 & 1431.5 & 0 & 0 \\
\hline \multicolumn{9}{|l|}{ CAPITAL COSTS } \\
\hline Maps & 66.7 & 83.8 & 66.8 & 83.8 & 75.0 & 94.8 & 0 & 0 \\
\hline Vehicles & 5095.1 & 4636.2 & 10190.3 & 9272.5 & 10827.2 & 9878.4 & 0.01 & 0.01 \\
\hline Spray pumps & 0.0 & 0.0 & 0.0 & 0.0 & 0.0 & 0.0 & 0 & 0 \\
\hline $\begin{array}{l}\text { Computers, other } \\
\text { equipment }\end{array}$ & 871.7 & 774.9 & 2330.0 & 2072.4 & 2439.0 & 2173.6 & 0 & 0 \\
\hline $\begin{array}{l}\text { Adult monitoring } \\
\text { equipment }\end{array}$ & 200.0 & 183.4 & 400.0 & 366.8 & 425.0 & 390.8 & 0 & 0 \\
\hline $\begin{array}{l}\text { SUBTOTAL RECURRENT } \\
\text { COSTS }\end{array}$ & $43,607.8$ & $40,513.6$ & $881,608.1$ & $899,171.1$ & $887,059.0$ & $904,465.6$ & 0.98 & 0.99 \\
\hline$\overline{\text { SUBTOTAL CAPITAL COSTS }}$ & $6,166.8$ & $5,594.5$ & $12,920.3$ & $11,711.6$ & $13,691.1$ & $12,442.8$ & 0.02 & 0.01 \\
\hline $\begin{array}{l}\text { TOTAL COSTS OF } \\
\text { PROGRAM }\end{array}$ & $49,774.5$ & $46,108.1$ & $894,528.3$ & $910,882.7$ & $900,750.2$ & $916,908.3$ & 1 & 1 \\
\hline $\begin{array}{l}\text { COST PER PERSON } \\
\text { PROTECTED }\end{array}$ & 0.08 & 0.08 & 1.47 & 1.49 & 1.48 & 1.5 & & \\
\hline
\end{tabular}

\section{Transport and vehicles}

One project vehicle would be required, along with motorcycles for the supervisors and bicycles for the LCPs. Fuel and maintenance costs of the vehicles and motorcycles were included. As described for previous locations, LCPs were responsible for the maintenance and care of bicycles, which were again treated as recurrent cost items.

\section{Adult mosquito monitoring}

Adult mosquito monitoring would be required year round in a stratified sample of 152 houses (on average approximately 1 sampling site $/ \mathrm{km}^{2}$ ) within the division. This activity would be carried out by the supervisors using locally produced clay pots [52]. A microscope and light source, as well as other supplies including ethanol, vials, Petri dishes, and dissecting kits, would be required for this activity, and subsequent mosquito identification would be carried out by the supervisors and programme manager.

\section{Mbita Division costing results}

The total financial and economic costs and cost per person are shown in Table 8 for scenario 1 (WG use only) and in Table 9 for scenario 2 (CG use only) both at mid-point prices. The cost per person protected using WG formulation for liquid application was US\$1.94, and the total annual programme costs were estimated at US $\$ 107,669$ to cover 55, 558 people located over $211 \mathrm{~km} 2$. Using CG the cost per person protected was US\$2.50, and the total programme cost was US\$138, 866.

The proportion of total programme costs allocated to CIF of the larvicide and protective clothing ranges from $19 \%$ if WG is used to $39 \%$ if CG is used. Staff salaries are a significant contributor to programme costs and range from $26 \%$ (CG usage) to 31\% (WG usage). 
Table 7 Staff structure of model LSM program for Mbita Division, western Kenya

\begin{tabular}{|c|c|c|c|c|}
\hline $\begin{array}{l}\text { Administrative } \\
\text { level }\end{array}$ & \multicolumn{2}{|c|}{ Number of staff } & $\begin{array}{c}\text { Time } \\
\text { contributed/ } \\
\text { period } \\
\text { employed per } \\
\text { year }\end{array}$ & Role and responsibilities \\
\hline \multicolumn{5}{|c|}{ PART TIME STAFF CONTRIBUTION TO PROGRAM } \\
\hline International & LSM expert & 1 & 2 months & $\begin{array}{l}\text { Advice on technical and programme management. Capacity building, support and trouble } \\
\text { shooting. }\end{array}$ \\
\hline Provincial & $\begin{array}{l}\text { Malaria } \\
\text { Control } \\
\text { Officer }\end{array}$ & 1 & 1 week & Engagement in stakeholder meetings. Site visits with NMCP \\
\hline \multirow[t]{2}{*}{ District } & $\begin{array}{l}\text { Public Heath } \\
\text { Officer }\end{array}$ & 1 & 1 hour/week & Involvement in weekly management meetings. \\
\hline & $\begin{array}{l}\text { Medical } \\
\text { Officer }\end{array}$ & 1 & 2.5 weeks & Involvement in weekly management meetings, sensitization of District health staff. \\
\hline \multicolumn{5}{|c|}{ FULL TIME PROGRAM STAFF } \\
\hline \multirow[t]{2}{*}{ District } & $\begin{array}{l}\text { Program } \\
\text { manager }\end{array}$ & 1 & 12 months & $\begin{array}{l}\text { Day to day programme management, procurement, financial management. Recruiting and } \\
\text { training Divisional supervisors }\end{array}$ \\
\hline & Driver & 1 & 12 months & Transport of program manager. Delivery of larvicide to supervisors/LCP. \\
\hline $\begin{array}{l}\text { Division/ } \\
\text { LSM-Area }\end{array}$ & Supervisors & 3 & 12 months & $\begin{array}{l}\text { Field work management, quality control, larval spot checks and adult collections, reporting } \\
\text { to programme manager. Evaluation and planning subsequent year's intervention. Training } \\
\text { of Supervisors and LCP Recruitment and supervision of LCP. }\end{array}$ \\
\hline $\begin{array}{l}5 \mathrm{~km}^{2} \text { LSM- } \\
\text { Unit }\end{array}$ & LCP & 28 & 12 months & Larvicide application, recording and reporting to supervisors \\
\hline
\end{tabular}

Taking the lowest value of WG prices reduced the cost per person to US $\$ 1.88$ and the total programme costs to US\$104, 266. Taking the highest value of WG prices increases the cost per person to US $\$ 1.98$ and total programme costs to US\$110, 090. Taking the lowest value of CG prices reduced the cost per person to US $\$ 2.37$ and the total programme costs to US\$131, 484 . Taking the highest published price increases the total programme costs to US $\$ 143,714$ and the cost per person protected increases to US $\$ 2.59$.

Full details of the assumptions regarding recurrent and capital inputs and unit costs are provided in the Additional File 4.

\section{Discussion}

The analyses presented here shows that cost of LSM using microbial larvicides varies in different eco-epidemiological settings in East Africa. The results show that for programmes using the same formulation (CG) larviciding costs the least in urban Dar es Salaam (US\$0.94), $60 \%$ more in the highly populated rural highlands of Vihiga District (US\$1.50) in a targeted approach and the most (US\$2.50) in Mbita Division where population density is lower and year round application is required. However, these costs are reduced substantially if the alternative formulation (WG) is used; in Vihiga this would reduce costs to US $\$ 0.79$ and in Mbita Division to US\$1.94. (See Table 10 for summary results).

In reality, as in the Dar es Salaam programme, a combination of formulations are likely to be required depending on the aquatic habitat types and ecology, implying that costs will fall between these two data points. Hence the appropriate product formulation used will influence costs. Habitats that have less vegetation will allow for greater use of the WG formulation which will generally result in less expensive programmes than those that require the CG formulation, even taking into account additional application equipment needs, such as spray pumps. Ultimately, product formulation decisions should be based on the local vector ecology and habitats as well as practical and operational considerations including operator and community preferences. Discussions with staff involved in various LSM projects revealed that the hand application of CG granule is often preferred over knapsack sprayer application $[26,49]$. It is important to note that the lowest cost product will not necessarily result in the most cost effective programme, because of the range of other factors that must be addressed in each programme.

Another key factor influencing cost is population density; because the intervention targets spatial areas, the higher the population density the lower the cost per person protected (other things being equal). Increasing the population protected will spread programme costs, especially fixed overheads, over a larger number of people and hence reduce per capita costs. Population density also has an impact on the number of individuals protected through application of larvicides in a given area.

The nature of malaria transmission and risk (influenced by other malaria control interventions) also has 
Table 8 LSM at shores of Lake Victoria in Mbita Division: Scenario 1 - Financial and economic costs using VectoBac WG formulation (in US\$ $\mathbf{2 0 0 6}$ at midpoint larvicide price)

\begin{tabular}{|c|c|c|c|c|c|c|c|c|}
\hline \multirow[t]{2}{*}{ Cost category } & \multicolumn{2}{|c|}{$\begin{array}{l}\text { Pre-implementation } \\
\text { Costs (YO) Total: }\end{array}$} & \multicolumn{2}{|c|}{$\begin{array}{l}\text { Implementation Year } \\
\text { Costs (Y1) Total: }\end{array}$} & \multicolumn{2}{|c|}{ Average Annual Costs: } & \multicolumn{2}{|c|}{ Proportion of Total Average: } \\
\hline & $\begin{array}{l}\text { Financial } \\
\text { Cost }\end{array}$ & $\begin{array}{l}\text { Economic } \\
\text { Cost }\end{array}$ & $\begin{array}{l}\text { Financial } \\
\text { Cost }\end{array}$ & $\begin{array}{c}\text { Economic } \\
\text { Cost }\end{array}$ & $\begin{array}{l}\text { Financial } \\
\text { Cost }\end{array}$ & $\begin{array}{l}\text { Economic } \\
\text { Cost }\end{array}$ & $\begin{array}{c}\text { Annual } \\
\text { Financial Cost }\end{array}$ & $\begin{array}{c}\text { Annual } \\
\text { Economic Cost }\end{array}$ \\
\hline \multicolumn{9}{|l|}{ RECURRENT COSTS } \\
\hline International staff costs & 9516.0 & 9516.0 & 19032.0 & 19032.0 & 20221.5 & 20275.6 & 0.16 & 0.18 \\
\hline NMCP/MoH staff costs & 0.0 & 0.0 & 344.3 & 847.8 & 344.3 & 847.8 & 0 & 0.01 \\
\hline $\begin{array}{l}\text { Programme staff } \\
\text { salaries }\end{array}$ & 14426.0 & 12370.3 & 39488.5 & 33861.4 & 41291.8 & 35478.0 & 0.33 & 0.31 \\
\hline $\begin{array}{l}\text { Larvicide (CIF), } \\
\text { protective cloth }\end{array}$ & 0.0 & 0.0 & 22601.9 & 21867.7 & 22601.9 & 21867.7 & 0.18 & 0.19 \\
\hline Staff Training & 0.0 & 0.0 & 2901.5 & 2437.2 & 2901.5 & 2437.2 & 0.02 & 0.02 \\
\hline $\begin{array}{l}\text { Community } \\
\text { sensitization }\end{array}$ & 0.0 & 0.0 & 144.6 & 121.5 & 144.6 & 121.5 & 0 & 0 \\
\hline $\begin{array}{l}\text { Operations Costs and } \\
\text { Overheads }\end{array}$ & 5087.2 & 4273.3 & 6739.7 & 5661.4 & 7375.6 & 6219.8 & 0.06 & 0.05 \\
\hline Transport & 6229.1 & 5232.5 & 8696.8 & 7305.3 & 9475.5 & 7989.1 & 0.08 & 0.07 \\
\hline $\begin{array}{l}\text { Adult mosquito } \\
\text { monitoring }\end{array}$ & 415.3 & 348.9 & 415.3 & 348.9 & 467.2 & 394.5 & 0 & 0 \\
\hline \multicolumn{9}{|l|}{ CAPITAL COSTS } \\
\hline Vehicles & 8813.2 & 8045.8 & 8813.2 & 8045.8 & 9914.8 & 9097.3 & 0.08 & 0.08 \\
\hline Spray pumps & 0.0 & 0.0 & 1500.0 & 1375.6 & 1500.0 & 1375.6 & 0.01 & 0.01 \\
\hline $\begin{array}{l}\text { Computers, other } \\
\text { equipment }\end{array}$ & 1136.7 & 1009.4 & 1147.0 & 1018.4 & 1289.1 & 1150.4 & 0.01 & 0.01 \\
\hline $\begin{array}{l}\text { Adult monitoring } \\
\text { equipment }\end{array}$ & 400.0 & 366.8 & 400.0 & 366.8 & 450.0 & 414.8 & 0 & 0 \\
\hline $\begin{array}{l}\text { SUBTOTAL RECURRENT } \\
\text { COSTS }\end{array}$ & 35673.7 & 31740.9 & 100364.7 & 91483.2 & 104823.9 & 95631.2 & 0.83 & 0.83 \\
\hline SUBTOTAL CAPITAL COSTS & 10349.9 & 9422.0 & 11860.2 & 10806.6 & 13153.9 & 12037.9 & 0.1 & 0.1 \\
\hline TOTAL COSTS OF PROGRAM & 46023.6 & 41162.9 & 112224.8 & 102289.8 & 117977.8 & 107669.2 & 1.00 & 1.00 \\
\hline $\begin{array}{l}\text { COST PER PERSON } \\
\text { PROTECTED }\end{array}$ & 0.83 & 0.74 & 2.02 & 1.84 & 2.12 & 1.94 & & \\
\hline
\end{tabular}

an impact on cost. The ability to target larvicididing in space (as in Vihiga and Mbita) and in time (Vihiga) provides opportunities to increase the efficiency of operations and thus reduce cost per person protected. In the highland area of Vihiga District, the programme costs are reduced (relative to the other programmes) because we hypothesized that treatment of breeding sites is not required year round to interrupt transmission which is seasonal.

Recently, a study was designed to investigate whether LSM in these sites can reduce malaria infections [28]. Evidence was provided of the impact of a double vector control intervention directed at both larval and adult mosquitoes. Vector control with microbial larvicides and LLINs combined, resulted in a two-fold reduction in new malaria infections compared with nets alone indicating that the addition of LSM to LLIN programmes can provide substantial additional protection against malaria parasites. Furthermore, the study indicated that vector densities only peaked during the main transmission season (March to June), when bednet coverage was high [28]. It is, therefore, likely that targeting larval control for a brief period at the end of the dry season and beginning of the long rainy season could be as efficient at controlling malaria as continual application throughout the year. This allows some programme staff to be employed on a seasonal basis, thus reducing costs. It is important to note that adequate monitoring does need to take place year round in such a programme to ensure the intervention is targeted optimally in relation to vector density and malaria transmission. However, the option of targeting interventions to the specific timing of the malaria transmission season presents options for reducing cost, which must be balanced against required surveillance costs (around US\$17, 000 in Dar es Salaam, where surveillance is relatively intensive). This is analogous to IRS in areas of seasonal or epidemic transmission where the cost effectiveness of the intervention has been shown to vary with timing in relation to the transmission season $[53,54]$. Research is 
Table 9 LSM at shores of Lake Victoria in Mbita Division: Scenario 2 - Financial and economic costs using VectoBac CG formulation (in US\$ 2006 at midpoint larvicide price)

\begin{tabular}{|c|c|c|c|c|c|c|c|c|}
\hline \multirow[t]{2}{*}{ Cost category } & \multicolumn{2}{|c|}{$\begin{array}{l}\text { Pre-implementation } \\
\text { Costs (Y0) Total: }\end{array}$} & \multicolumn{2}{|c|}{$\begin{array}{l}\text { Implementation Year } \\
\text { Costs (Y1) Total: }\end{array}$} & \multicolumn{2}{|c|}{ Average Annual Costs: } & \multicolumn{2}{|c|}{ Proportion of Total Average: } \\
\hline & $\begin{array}{l}\text { Financial } \\
\text { Cost }\end{array}$ & $\begin{array}{l}\text { Economic } \\
\text { Cost }\end{array}$ & $\begin{array}{l}\text { Financial } \\
\text { Cost }\end{array}$ & $\begin{array}{l}\text { Economic } \\
\text { Cost }\end{array}$ & $\begin{array}{l}\text { Financial } \\
\text { Cost }\end{array}$ & $\begin{array}{l}\text { Economic } \\
\text { Cost }\end{array}$ & $\begin{array}{c}\text { Annual } \\
\text { Financial Cost }\end{array}$ & $\begin{array}{c}\text { Annual } \\
\text { Economic Cost }\end{array}$ \\
\hline \multicolumn{9}{|l|}{ RECURRENT COSTS } \\
\hline International staff costs & 9516.0 & 9516.0 & 19032.0 & 19032.0 & 20221.5 & 20275.6 & 0.14 & 0.15 \\
\hline NMCP/MoH staff costs & 0.0 & 0.0 & 344.3 & 847.8 & 344.3 & 847.8 & 0 & 0.01 \\
\hline $\begin{array}{l}\text { Programme staff } \\
\text { salaries }\end{array}$ & 14426.0 & 12370.3 & 39488.5 & 33861.4 & 41291.8 & 35478.0 & 0.28 & 0.26 \\
\hline $\begin{array}{l}\text { Larvicide (CIF), } \\
\text { protective cloth }\end{array}$ & 0.0 & 0.0 & 55583.6 & 54440.5 & 55583.6 & 54440.5 & 0.37 & 0.39 \\
\hline Staff Training & 0.0 & 0.0 & 2901.5 & 2437.2 & 2901.5 & 2437.2 & 0.02 & 0.02 \\
\hline $\begin{array}{l}\text { Community } \\
\text { sensitization }\end{array}$ & 0.0 & 0.0 & 144.6 & 121.5 & 144.6 & 121.5 & 0 & 0 \\
\hline $\begin{array}{l}\text { Operations Costs and } \\
\text { Overheads }\end{array}$ & 5087.2 & 4273.3 & 6739.7 & 5661.4 & 7375.6 & 6219.8 & 0.05 & 0.04 \\
\hline Transport & 6229.1 & 5232.5 & 8696.8 & 7305.3 & 9475.5 & 7989.1 & 0.06 & 0.06 \\
\hline $\begin{array}{l}\text { Adult mosquito } \\
\text { monitoring }\end{array}$ & 415.3 & 348.9 & 415.3 & 348.9 & 467.2 & 394.5 & 0 & 0 \\
\hline \multicolumn{9}{|l|}{ CAPITAL COSTS } \\
\hline Vehicles & 8813.2 & 8045.8 & 8813.2 & 8045.8 & 9914.8 & 9097.3 & 0.07 & 0.07 \\
\hline Spray pumps & 0.0 & 0.0 & 0.0 & 0.0 & 0.0 & 0.0 & 0 & 0 \\
\hline $\begin{array}{l}\text { Computers and other } \\
\text { equipment }\end{array}$ & 1136.7 & 1009.4 & 1147.0 & 1018.4 & 1289.1 & 1150.4 & 0.01 & 0.01 \\
\hline $\begin{array}{l}\text { Adult monitoring } \\
\text { equipment }\end{array}$ & 400.0 & 366.8 & 400.0 & 366.8 & 450.0 & 414.8 & 0 & 0 \\
\hline $\begin{array}{l}\text { SUBTOTAL RECURRENT } \\
\text { COSTS }\end{array}$ & 35673.7 & 31740.9 & 133346.3 & 124056.0 & 137805.5 & 128204.0 & 0.92 & 0.92 \\
\hline SUBTOTAL CAPITAL COSTS & 10349.9 & 9422.0 & 10360.2 & 9431.1 & 11653.9 & 10662.4 & 0.08 & 0.08 \\
\hline TOTAL COSTS OF PROGRAM & 46023.6 & 41162.9 & 143706.5 & 133487.0 & 149459.5 & 138866.4 & 1 & 1 \\
\hline $\begin{array}{l}\text { COST PER PERSON } \\
\text { PROTECTED }\end{array}$ & 0.83 & 0.74 & 2.59 & 2.4 & 2.69 & 2.5 & & \\
\hline
\end{tabular}

underway to identify appropriate targeting strategies including LSM [55-57].

Programme structure will also drive costs, and in Dar es Salaam the management structure and number of employees is higher, reflecting the operational realities of working in an urban environment. However, the additional costs of this programme structure are moderated by higher population density. In Mbita Division,

Table 10 Summary of Costing Results (US\$2006) from Dar es Salaam, Vihiga District, and Mbita Division

\begin{tabular}{|c|c|c|c|c|c|c|c|c|}
\hline \multirow{3}{*}{$\begin{array}{l}\text { Location } \\
\text { (population protected) }\end{array}$} & \multirow[t]{3}{*}{ Scenario } & \multirow[t]{3}{*}{ Cost type } & \multicolumn{6}{|c|}{ Price of Larvicide } \\
\hline & & & \multicolumn{2}{|c|}{ Low } & \multicolumn{2}{|c|}{ Mid } & \multicolumn{2}{|c|}{ High } \\
\hline & & & Total cost & Cost/person & Total cost & Cost/person & Total cost & Cost/person \\
\hline \multirow[t]{2}{*}{ Dar es Salaam $(592,338)$} & CG & Financial & 632,048 & 1.07 & 669,241 & 1.13 & 693,663 & 1.17 \\
\hline & & Economic & 530,866 & 0.90 & 559,476 & 0.94 & 578,262 & 0.98 \\
\hline \multirow[t]{4}{*}{ Vihiga $(609,324)$} & WG & Financial & 477,050 & 0.78 & 520,032 & 0.85 & 550,603 & 0.90 \\
\hline & & Economic & 437,753 & 0.72 & 480,735 & 0.79 & 511,306 & 0.84 \\
\hline & CG & Financial & 807,510 & 1.33 & 900,750 & 1.48 & 961,972 & 1.58 \\
\hline & & Economic & 823,668 & 1.35 & 916,908 & 1.50 & 978,130 & 1.61 \\
\hline \multirow[t]{4}{*}{ Mbita $(55,558)$} & WG & Financial & 114,574 & 2.06 & 117,978 & 2.12 & 120,398 & 2.17 \\
\hline & & Economic & 104,266 & 1.88 & 107,669 & 1.94 & 110,090 & 1.98 \\
\hline & CG & Financial & 142,077 & 2.56 & 149,459 & 2.69 & 154,307 & 2.78 \\
\hline & & Economic & 131,484 & 2.37 & 138,866 & 2.50 & 143,714 & 2.59 \\
\hline
\end{tabular}


the programme staff structure is minimal, however, the number of people protected is also lower, which means that fixed costs, such as international expert support and programme staff salaries, contribute a larger portion to per capita costs. Costs per person might decrease if the entire Suba district would be targeted for LSM since this could still be done with one programme manager and the estimated amount of external support. Identifying the optimal operational scale and management structure for potential LSM programmes will be critical area where vector control programmes may need support.

A further consideration for costs is the inclusion of the control of nuisance mosquitoes (Culex spp.) in a programme. This was outside the scope of this project but will be a question raised especially in the urban context where, like in Dar es Salaam, culicine mosquitoes are responsible for over 100 bites per exposed person per night [26]. While targeting the interventions only at potential Anopheles breeding sites can reduce costs, it may not improve cost effectiveness. Access to breeding sites on private property is essential and so a withdrawal of communities' support may reduce effectiveness [58-60]. The control of nuisance mosquitoes in Dar es Salaam to date remained unsatisfactory, the overall culicine densities remained high in the intervention wards due to the large number of closed habitats like pit latrines, soakage pits, septic tanks and water storage tanks, which were not included in the weekly larvicide applications [26]. Efficient strategies including the implementation of environmental modifications need to be developed and costed to address the nuisance biting problem in urban areas, especially since Culex and Aedes mosquitoes are also important vectors of diseases, such as lymphatic filariasis, encephalitis, dengue and chikungunya in many parts of the world [61].

To date very little information is available for the costs of LSM in contemporary Africa. A basic cost estimation was attempted by Fillinger and Lindsay estimating that the cost of protecting the human population in the study area of Mbita town was approximately US $\$ 0.90$ per person protected [27]. Our results for Mbita Division are higher for a number of reasons. First, we considered all programme costs, rather than only direct expenditure on consumables and salaries. We have included a complete staffing structure required to operate a programme at scale, including external technical assistance, vehicles, office space and overheads. Second, variation in population density is very important. Fillinger and Lindsay protected 8, 000 people in an urbanized setting of approximately $4.5 \mathrm{~km}^{2}$ in Mbita town [27]. Here costs are estimated for the whole of Mbita Division, where average population density is three times lower.
The costing methods used in this analysis are standard and consistent with those used in other economic evaluations of malaria control interventions [62-64]. Importantly, this paper enables the larval control costs be compared to other malaria and health interventions, such as IRS and ITNs [53]. However, the output indicator used in this report is person protected per year. This indicator was chosen because at the time of the analysis there was insufficient data on the epidemiological impact of larval control to estimate the additional benefits (e.g. malaria cases prevented, malaria-related deaths averted, or disability adjusted life years [DALYs] saved) of using larval control in conjunction with other malaria vector control interventions. Forthcoming evidence on the effectiveness of LSM on malaria prevention can be incorporated into these costing models.

\section{Conclusions}

The integration of LSM into ongoing malaria control programmes is likely to be most effective where transmission is moderate or low and where mosquito breeding sites are contained and well-defined [14,27,28,31]. These include, but are not restricted to, highland areas, desert-fringe areas, urban settings and areas prone to epidemics. The current success of ITN programmes to reduce malaria transmission will result in far more areas with low and focal malaria transmission; representing a great opportunity for IVM programmes, including LSM, to maintain hard won gains and aim for even further reductions. Cost implications are of major importance for deciding which interventions to use in an IVM programme, yet these data are lacking. This is particularly important since the World Health Organisation is encouraging the adoption of IVM for the control of malaria and other vector borne diseases [4]. This economic analysis bears out the previously highlighted suggestion that focusing LSM efforts in areas of high population density where spatial and/or temporal targeting is possible offers a low cost intervention in terms of cost per person protected per year. Nevertheless, such settings are not only found in urban areas.

During the course of this analysis, three potential sites for larval control programmes of different sizes and environmental settings were visited. In each, an operational larval control programme or research study was currently operating. The individuals consulted during development of these costing models described, based on their local experiences, the needs for a large-scale operational LSM programmes that would be appropriate for each setting; where needed, specific programmatic challenges were addressed with locally appropriate solutions. While careful consideration of the ecological and operational conditions in each setting is required, the cost models developed here will facilitate cost 
implication evaluation for alternative programme approaches and structures.

In appropriate settings and based on the current entomological evidence, LSM is an attractive malaria control intervention in terms of cost. The cost per person protected by larval control in this analysis ranged from US $\$ 0.79$ to US $\$ 2.50$, which is comparable with other malaria interventions. For example the cost of IRS ranges from US $\$ 0.88$-4.94 per person protected (US $\$ 2000$ ), the cost per treated net year for conventional ITNs was found to range from US\$1.21-6.05 and for LLINs US\$1.38-1.90 (2005 US\$) [54,65]. Analyses such as the Disease Control Priorities Project have described malaria control interventions as among the most cost effective health interventions and have recommended investment in malaria control as an essential development and poverty reduction strategy [66]. The analysis presented here addresses one of the major concerns hampering the advocacy of LSM to date, the perception that this intervention is very expensive. The presented costing analysis indicates that LSM is within the cost range of other interventions that have been described as among the most cost effective. Therefore, larval control can be a complementary tool in the malaria control effort in selected settings. Malaria control programme managers and other decision makers in national and international organizations should consider LSM as part of an IVM strategy, in conjunction with ITNs and/or IRS. However, LSM should not be considered as a replacement for other vector control methods or as a standalone intervention.

Once further evidence is available with which to estimate the additional health benefits of using LSM in conjunction with other vector control interventions, it will be possible to complete an analysis of the comparative cost effectiveness of various combinations of IRS, ITNs, and LSM. Other larval control products are available on the market, including insect growth regulators (IGR), synthetic organic chemicals, and microbials other than those considered in this paper. Investigation into the cost and programmatic implications of these products and/or formulations should be considered (e.g., considering the costs and risks associated with insecticide resistance development, impacts on non-target organisms, and worker safety).

\section{Additional material}

Additional file 1: Larvicide product price, exchange rates and annulization factors. The document presents tables with the product prices used for the costing, exchange rates used for currency conversion and the annulization factor and discount rates used for capital costs.

Additional file 2: Dar es Salaam: Recurrent and capital unit costs The file shows two tables itemizing the recurrent cost units and the capital cost units on which the economic costing is based.
Additional file 3: Vihiga District: Recurrent and capital unit costs The file shows two tables itemizing the recurrent cost units and the capital cost units on which the economic costing is based.

Additional file 4: Mbita Division: Recurrent and capital unit costs. The file shows two tables itemizing the recurrent cost units and the capital cost units on which the economic costing is based.

\section{Acknowledgements}

The following people were involved in the data collection stages of this paper and are gratefully acknowledged: Andrew Githeko, Steven Munga and Bryson Ndenga from KEMRI, Kisumu; Gabriel Didah, Emmanuel Mushinzimana, Ibrahim Kiche and George Sonye from Nagasaki University Nairobi Research Station KEMRI-NUITM Project; Felix Ngiru and David Ooko from the Suba District Health Management Team; Khadija Kannady, Abdulla Hamed, Bryson Shoo, Isaak Vesso from the UMCP Dar es Salaam, Tanzania; Jo Mulligan and Gerry Killeen from the Ifakara Health Institute, Tanzania; Chris Gilbert from Crown Agents UK; Steven Lindsay from the London School of Hygiene and Tropical Medicine, UK; Jason Clark, Ernest Dankwa and Steve Krause from Valent BioSciences Corp. USA, Gene Brantly and Jennifer Van Kirk from RTI International, USA; Julie Atherton, Angela Honor, Ema Kelly and Katie Nield from LATH, UK and Barbara Addy, Charles

Llewellyn, Mike Macdonald and Renee Selgado from USAID Washington and Dar es Salaam. Thanks to Lucy Tusting for help with the endnote library. This study was funded by the United States Agency of International Development (USAID) and Valent BioSciences Corp. through RTI International. UF is supported through a National Institute of Health $(\mathrm{NIH})$ Grant No. R01 Al082537.

\section{Author details}

'Liverpool School of Tropical Medicine, Pembroke Place, Liverpool L3 5QA, UK. ${ }^{2}$ Department of Disease Control, London School of Hygiene and Tropical Medicine, Keppel Street, London WC1E 7HT, UK. International Centre of Insect Physiology and Ecology, Thomas Odhiambo Campus, Mbita 40305, Kenya.

\section{Authors' contributions}

EW and UF collated all the data necessary for analyses, UF advised on the design of the model programmes and ingredients and EW did the costing analyses. Both authors jointly wrote the manuscript, read and approved the final version.

\section{Competing interests}

This work was partially supported by Valent BioSciences Corp., the commercial manufacturer of the microbial larvicide costed. Nevertheless, none of the funders of this work had any role in the analysis or interpretation of the results, nor in the drafting of the manuscript.

Received: 14 September 2011 Accepted: 8 November 2011 Published: 8 November 2011

\section{References}

1. WHO: World Malaria Report 2009 Geneva: World Health Organization; 2009

2. Slutsker L, Newman RD: Malaria scale-up progress: is the glass half-empty or half-full? Lancet 2009, 373:11-13.

3. The President's Malaria Initiative. Technical areas. Indoor residual spaying. [http://www.pmi.gov/technical/irs/index.html].

4. WHO: WHO position statement on integrated vector management. Weekly epidemiological record 2008, 20:177-184.

5. Killeen GF, Fillinger U, Kiche I, Gouagna LC, Knols BG: Eradication of Anopheles gambiae from Brazil: lessons for malaria control in Africa? Lancet Infect Dis 2002, 2:618-627.

6. Kitron $U$, Spielman A: Suppression of transmission of malaria through source reduction: antianopheline measures applied in Israel, the United States and Italy. Rev Infect Dis 1989, 11:391-406.

7. Russell PF: Man's mastery of malaria London: Oxford University Press; 1955.

8. Shousha AT: The eradication of Anopheles gambiae from Upper Egypt 1942-1945. Bull World Health Organ 1948, 1:309-342. 
9. Soper FL, Wilson DB: Anopheles gambiae in Brazil The Rockefeller Foundation; 1943

10. Takken W, Snellen WB, Verhave JP, Knols BG: Environmental measures for malaria control in Indonesia - an historical review on species sanitation Wageningen: Wageningen Agricultural University Papers; 1990.

11. Utzinger J, Tozan $Y$, Singer BH: Efficacy and cost-effectiveness of environmental management for malaria control. Trop Med Int Health 2001, 6:677-687

12. Watson M: African highway: the battle for health in Central Africa London: John Murray; 1953

13. Fillinger $U$, Knols BG, Becker N: Efficacy and efficiency of new Bacillus thuringiensis var israelensis and Bacillus sphaericus formulations against Afrotropical anophelines in Western Kenya. Trop Med Int Health 2003, 8:37-47.

14. Fillinger U, Sonye G, Killeen GF, Knols BG, Becker N: The practical importance of permanent and semipermanent habitats for controlling aquatic stages of Anopheles gambiae sensu lato mosquitoes: operational observations from a rural town in western Kenya. Trop Med Int Health 2004, 9:1274-1289.

15. Najera JA, Zaim M: Malaria Vector Control - Decision Making Criteria and Procedures for Judicious Use of Insecticides WHO Pesticide Evaluation Scheme; 2002.

16. Gu W, Utzinger J, Novak RJ: Habitat-Based Larval Interventions: A New Perspective for Malaria Control. Am J Trop Med Hyg 2008, 78:2-6.

17. Ranson H, Abdallah H, Badolo A, Guelbeogo WM, Kerah-Hinzoumbe C, Yangalbe-Kalnone E, Sagnon N, Simard F, Coetzee M: Insecticide resistance in Anopheles gambiae: data from the first year of a multi-country study highlight the extent of the problem. Malar J 2009, 8:299.

18. Bayoh MN, Mathias DK, Odiere MR, Mutuku FM, Kamau L, Gimnig JE, Vulule JM, Hawley WA, Hamel MJ, Walker ED: Anopheles gambiae: historical population decline associated with regional distribution of insecticide-treated bed nets in western Nyanza Province, Kenya. Malar J 2010, 9:62.

19. Mushinzimana E, Munga S, Minakawa N, Li L, Feng CC, Bian L, Kitron U, Schmidt $C$, Beck $L$, Zhou G, et al: Landscape determinants and remote sensing of anopheline mosquito larval habitats in the western Kenya highlands. Malar Jl 2006, 5:13.

20. Yohannes M, Haile M, Ghebreyesus T, Witten K, Getachew A, Byass P, Lindsay S: Can source reduction of mosquito larval habitat reduce malaria transmission in Tigray, Ethiopia? Trop Med Int Health 2005, 10:1274-1285.

21. Gu W, Novak R: Habitat-based modeling of impacts of mosquito larval interventions on entomological inoculation rates, incidence, and prevalence of malaria. Am J Trop Med Hyg 2005, 73:546-552.

22. Minakawa N, Munga S, Atieli F, Mushinzimana E, Zhou G, Githeko AK, Yan G: Spatial distribution of anopheline larval habitats in Western Kenyan highlands: effects of land cover types and topography. Am J Trop Med Hyg 2005, 73:157-165.

23. Le Menach A, McKenzie FE, Flahault A, Smith DL: The unexpected importance of mosquito oviposition behaviour for malaria: nonproductive larval habitats can be sources for malaria transmission. Malar J 2005, 4:23

24. Mutuku FM, Bayoh MN, Gimnig JE, Vulule JM, Kamau L, Walker ED, Kabiru E, Hawley WA: Pupal habitat productivity of Anopheles gambiae complex mosquitoes in a rural village in Western Kenya. Am J Trop Med Hyg 2006, 74:54-61.

25. Shililu J, Ghebremeskel T, Seulu F, Mengistu S, Fekadu H, Zerom M, Asmelash GE, Sintasath D, Mbogo C, Githure J, et al: Seasonal abundance, vector behavior, and malaria parasite transmission in Eritrea. J Am Mosa Control Assoc 2004, 20:155-164.

26. Fillinger U, Kannady K, William G, Vanek MJ, Dongus S, Nyika D, Geissbuhler Y, Chaki PP, Govella NJ, Mathenge EM, et al: A tool box for operational mosquito larval control: preliminary results and early lessons from the Urban Malaria Control Programme in Dar es Salaam, Tanzania. Malar J 2008, 7:20

27. Fillinger $U$, Lindsay SW: Suppression of exposure to malaria vectors by an order of magnitude using microbial larvicides in rural Kenya. Trop Med Int Health 2006, 11:1629-1642.

28. Fillinger U, Ndenga B, Githeko A, Lindsay SW: Integrated malaria vector control with microbial larvicides and insecticide-treated nets in western Kenya: a controlled trial. Bull World Health Organ 2009, 87:655-665.
29. Geissbuhler Y, Kannady K, Chaki PP, Emidi B, Govella NJ, Mayagaya V, Kiama M, Mtasiwa D, Mshinda H, Lindsay SW, et al: Microbial larvicide application by a large-scale, community-based program reduces malaria infection prevalence in urban Dar es Salaam, Tanzania. PloS one 2009, 4: e5107.

30. Nyarango PM, Gebremeskel T, Mebrahtu G, Mufunda J, Abdulmumini U, Ogbamariam A, Kosia A, Gebremichael A, Gunawardena D, Ghebrat Y, Okbaldet $Y$ : A steep decline of malaria morbidity and mortality trends in Eritrea between 2000 and 2004: the effect of combination of control methods. Malar J 2006, 5:33.

31. RBM: Global malaria action plan Roll Back Malaria Partnership; 2008.

32. Yukich J, Tediosi F, Lengeler C: Operations, costs and cost-effectiveness of five insecticide-treated net programs (Eritrea, Malawi, Tanzania, Togo, Senegal) and two indoor residual spray programs (Kwa-Zulu-Natal, Mozambique) USAID; 2007

33. Geissbuhler Y, Chaki P, Emidi B, Govella NJ, Shirima R, Mayagaya $V$, Mtasiwa D, Mshinda H, Fillinger U, Lindsay SW, et al: Interdependence of domestic malaria prevention measures and mosquito-human interactions in urban Dar es Salaam, Tanzania. Malar J 2007, 6:126.

34. Dongus S, Nyika D, Kannady K, Mtasiwa D, Mshinda H, Fillinger U, Drescher AW, Tanner M, Castro MC, Killeen GF: Participatory mapping of target areas to enable operational larval source management to suppress malaria vector mosquitoes in Dar es Salaam, Tanzania. Int J Health Geogr 2007, 6:37.

35. Dongus S, Nyika D, Kannady K, Mtasiwa D, Mshinda H, Gosoniu L, Drescher AW, Fillinger U, Tanner M, Killeen GF, Castro MC: Urban agriculture and Anopheles habitats in Dar es Salaam, Tanzania. Geospat Health 2009, 3:189-210.

36. Guyatt HL, Corlett SK, Robinson TP, Ochola SA, Snow RW: Malaria prevention in highland Kenya: indoor residual house-spraying vs. insecticide-treated bednets. Trop Med Int Health 2002, 7:298-303.

37. Shanks GD, Hay SI, Stern DI, Biomndo K, Snow RW: Meteorologic influences on Plasmodium falciparum malaria in the Highland Tea Estates of Kericho, Western Kenya. Emerg Infect Dis 2002, 8:1404-1408.

38. Hay SI, Were EC, Renshaw M, Noor AM, Ochola SA, Olusanmi I, Alipui N, Snow RW: Forecasting, warning, and detection of malaria epidemics: a case study. Lancet 2003, 17:1705-1706.

39. Munga S, Minakawa N, Zhou G, Mushinzimana E, Barrack OO, Githeko AK, Yan G: Association between land cover and habitat productivity of malaria vectors in western Kenyan highlands. Am J Trop Med Hyg 2006, 74:69-75.

40. Kenya 1999 population and housing census Nairobi: Central Bureau of Statistics, Ministry of Finance and Planning; 2002.

41. Githeko AK, Ayisi JM, Odada PK, Atieli FK, Ndenga BA, Githure JI, Yan G: Topography and malaria transmission heterogeneity in western Kenya highlands: prospects for focal vector control. Malar J 2006, 5:107.

42. Minakawa N, Mutero CM, Githure Jl, Beier JC, Yan G: Spatial distribution and habitat characterization of anopheline mosquito larvae in Western Kenya. Am J Trop Med Hyg 1999, 61:1010-1016.

43. Drummond MB, Schulpher MJ, Torrance GW, O'Brien B, Stoddart GL: Methods for the economic evaluation of health care programmes. 3 edition. Oxford: Oxford University Press; 2005

44. Gold MR, Russel LB, Siegel JE, Weinstein MC, (Eds.): Cost-effectiveness in health and medicine. New York: Oxford University Press; 1996.

45. Goodman CA, Mutemi WM, Baya EK, Willetts A, Marsh V: The costeffectiveness of improving malaria home management: shopkeeper training in rural Kenya. Health Policy Plan 2006, 21:275-288.

46. WHO: International programme on chemical safety (IPCS): Microbial pest control agent Bacillus thuringiensis. Environmental Health Criteria 1999, 217:1-105.

47. WHO: Pesticides and their application. 6 edition. Geneva: World Health Organization; 2006.

48. WHO: Report of the WHO consultation on integrated vector management (IVM) Geneva: World Health Organization; 2007.

49. Majambere S, Lindsay SW, Green C, Kandeh B, Fillinger U: Microbial larvicides for malaria control in The Gambia. Malar J/ 2007, 6:76.

50. Govella NJ, Chaki PP, Geissbuhler Y, Kannady K, Okumu F, Charlwood JD Anderson RA, Killeen GF: A new tent trap for sampling exophagic and endophagic members of the Anopheles gambiae complex. Malar J 2009, 8:157. 
51. Sikulu M, Govella NJ, Ogoma SB, Mpangile J, Kambi SH, Kannady K, Chaki PC, Mukabana WR, Killeen GF: Comparative evaluation of the Ifakara tent trap- $B$, the standardized resting boxes and the human landing catch for sampling malaria vectors and other mosquitoes in urban Dar es Salaam, Tanzania. Malar J 2009, 8:197.

52. Odiere MR, Bayoh MN, Gimnig J, Vulule J, Irungu L, Walker E: Sampling outdoor resting Anopheles gambiae and other mosquitoes (Diptera: Culicidae) in western Kenya with clay pots. J Med Entomol 2007, 44:14-22.

53. Worrall E, Connor SJ, Thomson MC: A model to simulate the impact of timing, coverage and transmission intensity on the effectiveness of indoor residual spraying (IRS) for malaria control. Trop Med Int Health 2007, 12:75-88.

54. Worrall E, Connor SJ, Thomson MC: Improving the cost-effectiveness of IRS with climate informed health surveillance systems. Malar J 2008, 7:263.

55. AvecNet (African Vector Control: New Tools). [http://www.avecnet.eu/]

56. Gates award: Eliminating malaria by a targeted interventions. [http:// www.ncmls.eu/news/gates-award/].

57. Oviposition behaviour of the malaria mosquito Anopheles gambiae . [http://www.kth.se/en/che/divisions/orgkem/research/ecochem/projects/ malaria-1.72884]

58. Bang YH, Mrope FM, Sabuni IB: Changes in mosquito populations associated with urbanization in Tanzania. East Afr Med J 1977, 54:403-410.

59. Chavasse DC, Lines JD, Ichimori $K$ : The relationship between mosquito density and mosquito coil sales in Dar es Salaam. Trans $R$ Soc Trop Med Hyg 1996, 90:493.

60. Stephens C, Masamu ET, Kiama MG, Keto AJ, Kinenekejo M, Ichimori K Lines J: Knowledge of mosquitos in relation to public and domestic control activities in the cities of Dar es Salaam and Tanga. Bull World Health Organ 1995, 73:97-104

61. Castro MC, Kanamori S, Kannady K, Mkude S, Killeen GF, Fillinger U: The importance of drains for the larval development of lymphatic filariasis and malaria vectors in Dar es Salaam, United Republic of Tanzania. PLoS NTD 2010, 4:e693.

62. Breman JG, Mills A, Snow RW, Mulligan JA, Lengeler C, Mendis K, Sharp B, Morel C, Marchesini P, White NJ, et al: Conquering Malaria. In Disease Control Priorities in Developing Countries. 2 edition. Edited by: Jamison DT, Breman JG, Measham AR, Alleyne G, Claeson M, Evans DB, Jha P, Mills A, Musgrove P. Washington (DC): World Bank; 2006:

63. Goodman CA, Coleman M, Mills A, (Eds): Economic analysis of malaria control in Sub-Saharan Africa. Global Forum for Health Research; 2000.

64. Goodman CA, Coleman PG, Mills AJ: Cost-effectiveness of malaria control in sub-Saharan Africa. Lancet 1999, 354:378-385.

65. Yukich J, Lengeler C, Tediosi F, Brown N, Mulligan J, Chavasse D, Stevens W, Justino J, Conteh L, Maharaj R, et al: Costs and consequences of largescale vector control for malaria. Malar J 2008, 17:258.

66. Disease Control Priorities Project. [http://www.dcp2.org]

\section{Submit your next manuscript to BioMed Central and take full advantage of:}

- Convenient online submission

- Thorough peer review

- No space constraints or color figure charges

- Immediate publication on acceptance

- Inclusion in PubMed, CAS, Scopus and Google Scholar

- Research which is freely available for redistribution

Submit your manuscript at www.biomedcentral.com/submit 